\title{
Bankrupting Trademarks
}

\author{
Xuan-Thao N. Nguyen
}

\section{TABLE OF CONTENTS}

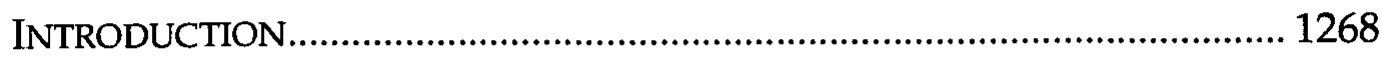

I. TRADEMARKS, LICENSES, AND PROPERTY ……............................. 1271

A. The Rise of Trademarks ........................................................... 1271

B. Trademark Licensing and Quality Control............................... 1275

C. Trademarks and the Internet .................................................... 1281

II. THE INTELLECTUAL PROPERTY BANKRUPTCY PARADIGM ............... 1286

A. The Exclusion of Trademarks From Intellectual Property

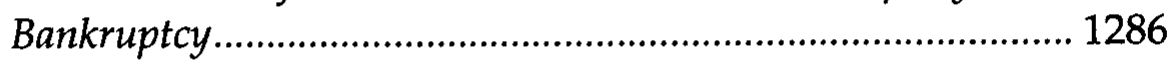

B. The Intellectual Property Licenses in Bankruptcy Act .............. 1289

C. Intellectual Property Paradigm - Patents, Trade Secrets, and

Copyrights Only ........................................................................ 1293

III. PERPETUATING THE PARADIGM........................................................ 1300

IV. RETHINKING TRADEMARK PROPERTY ............................................. 1302

A. The Trademark as the Global Domain Name .............................. 1303

B. Trademark Licenses Integrated With Other Intellectual

Property ............................................................................... 1307

V. ENDING THE EXCLUSION OF TRADEMARKS..................................... 1310

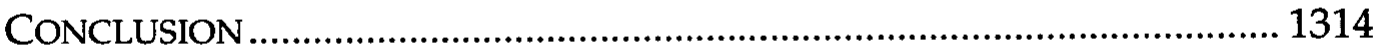

- Associate Professor of Law, Southern Methodist University Dedman School of Law; J.D., Northeastern University School of Law; B.A., Oberlin College. Intellectual Property Associate, Fried, Frank, Harris, Shriver \& Jacobson (New York City); Intellectual Property Associate, Pryor, Cashman, Sherman \& Flynn, LLP (New York City). Versions of this paper were presented at the Judicial Conference for Bankruptcy Judges in September 2003 at SMU and at the INTA Leadership Meeting in November 2003 in Boca Raton. Special thanks to Professor David Epstein for organizing the Federal Judicial Center SMU Judges Program. The author is grateful for the generous writing grant provided by SMU Dedman School of Law. The author thanks Lora Moffatt, Partner, Salans \& Hertzfield; Claudia Cantarella, Counsel, Willkie Farr \& Gallagher; and Ilene Tannen, Partner, Pennie \& Edmonds for their inspiration and encouragement of the development of scholarship in Intellectual Property Bankruptcy. Many thanks to Bruce Muck, Head Research Services, SMU Underwood Law Library for his professional research support. Special thanks to Erik Darwin Hille and our son Khai-Leif Nguyen-Hille for their love, kindness, and support. 


\section{INTRODUCTION}

The explosive growth of technology in the last two decades has vastly expanded intellectual property jurisprudence and elevated intellectual property to a heightened status in the marketplace. ${ }^{1}$ Indeed, a company's intellectual property assets may now be its most valuable corporate assets. ${ }^{2}$ Moreover, the property value of some trademarks is significantly greater than that of the trademark owner's physical assets. ${ }^{3}$

The term "intellectual property" is commonly understood to include patents, trade secrets, copyrights, and trademarks. ${ }^{4}$ Yet a paradigm has

1 See David H. Kennedy, Structuring Deals Involving Significant Intellectual Property Assets, 740 PLI/Pat 947, 991 (2003) (recognizing important role of intellectual property in modern economy and observing that "[m]ulti-billion dollar companies more and more frequently have their origins in a set of ideas, and the entire life cycles of world-leading enterprises are governed by the legal relationships created between inventors, investors, producers and consumers of intellectual property."). Intellectual property also greatly influences changes across major sectors of society. Richard S. Gruner, Intangible Inventions: Patentable Subject Matter for an Information Age, 35 LoY. L.A. L. REV. 355, 360-61 (2002) (noting that "information-processing innovation is at the heart of many of the most important changes now underway in our individual, social, business, and governmental activities.").

2 See Bruce A. Lehman, Intellectual Property: America's Competitive Advantage in the 21st Century, 31 COLUM. J. WORLD Bus. 6, 10 (1996) ("Both new corporations and restructured corporations and industries are finding that one of their most valuable assets is their intellectual property."); see also William J. Murphy, Proposal for a Centralized and Integrated Registry for Security Interests in Intellectual Property, 41 IDEA 297, 297 (2002) (observing that in knowledge-based economy intellectual property assets, not buildings and machinery, are most relevant and valuable assets); Jerry T. Myers, Where Have All the Assets Gone? Finding the Intangible Value of the Bankrupt E-commerce Company, 697 PLI/Pat 41, 53 (2002) (stating that for e-commerce companies intellectual property rights are among most valuable assets).

${ }^{3}$ Robert N. Klieger, Trademark Dilution: The Whittling Away of the Rational Basis for Trademark Protection, 58 U. PITT. L. REV. 789, 790-91 (1997) (stating that trademarks as brands have become more valuable than physical assets and other forms of intellectual property). "Put simply, 'a trademark is that which makes tomorrow's business something more than an accident."' Id. (quoting UNTTED STATES TRADEMARK ASSOC., TRADEMARKS IN ADVERTISING AND SELLING 1 (1966)); see also Thomas D. Drescher, The Transformation and Evolution of Trademarks - From Signals to Symbols to Myth, 82 TRADEMARK REP. 301, 301-02 (1992) ("The production plants and inventories of The Coca-Cola Company could go up in flames overnight.... Yet, on the following morning, there is not a bank... that would not lend this Company the funds necessary for rebuilding, accepting as security only the inherent goodwill in its trademarks 'Coca-Cola' and 'Coke."' (quoting Julius R. Lunsford, Jr., Good Will in Trade Marks: Coca-Cola and Coke, THE COCA-COLA BOTTLER 27, Mar. 1955, at 27)).

4 See, e.g., Terri Branstetter Cohen, Anti-Circumvention: Has Technology's Child Turned Against Its Mother?, 36 VAND. J. TRANSNAT'L L. 961, 964 (2003) (stating that intellectual property laws traditionally encompass four separate and distinct types of intangible property: patents, trademarks, copyrights, and trade secrets); Jean Raymond Homere, Intellectual Property Rights Can Help Stimulate the Economic Development of Least Developed 
been constructed and enforced over the last fifteen years wherein only patents, trade secrets, and copyrights are included. ${ }^{5}$ The paradigm specifically excludes trademarks from some of the protections afforded to the other three types of intellectual property. ${ }^{6}$ Under the paradigm, the licensees of patents, trade secrets, and copyrights are allowed to retain the right to use the licenses after the licensor has petitioned for bankruptcy and decided to sever the license agreements.' On the other hand, a bankrupt licensor's severing of a trademark license agreement extinguishes the licensee's license rights. ${ }^{8}$ This Intellectual Property Bankruptcy Paradigm ("the Paradigm") is embodied in the Intellectual Property Licenses in Bankruptcy Act. ${ }^{9}$

The Paradigm calls into question the normative values given to patents, trade secrets, and copyrights, on one end of the spectrum, and trademarks, on the other end. ${ }^{10}$ The fast changing role of trademarks in Internet global communication and commerce calls into question the exclusion of trademarks from the Paradigm. ${ }^{11}$ Further, the modern and less restrictive quality control practices and the integration of trademarks into the bundle of licensed rights in the marketplace undermine the

Countries, 27 COLUM.-VLA J.L. \& ARTS 277, 279 (2004) (stating that intellectual property rights include patents, trade secrets, trademarks, and copyrights); Thomas J. Krumenacher, Note, Protection for Indigenous Peoples and Their Traditional Knowledge: Would a Registry System Reduce the Misappropriation of Traditional Knowledge?, 8 MARQ. INTELL. PROP. L. REV. 143,143 (2004) (noting that conventional branches of intellectual property include patents, copyrights, trade secrets, and trademarks).

5 See infra Part II.

6 See infra Part II.

7 See generally Schlumberger Res. Mgmt. Servs., Inc. v. Cellnet Data Sys., Inc., 327 F.3d 242, 250 (3d Cir. 2003); Encino Bus. Mgmt., Inc. v. Prize Frize, Inc., 32 F.3d 426, 429 (9th Cir. 1994).

8 See generally In re HQ Global Holdings, Inc., 290 B.R. 507 (Bankr. D. Del. 2003); In re Centura Software Corp., 281 B.R. 660 (Bankr. N.D. Cal. 2002).

9 Act of Oct. 18, 1988, Pub. L. No. 100-506, 102 Stat. 2538 (codified as 11 U.S.C. $\S 365(\mathrm{n})(2000))$.

10 A recent article authored by Professors Gideon Parchomovsky and Peter Siegelman offers a fresh examination of the synergy between patents and trademarks, challenging the traditional view of discrete and fragmented protection. See Gideon Parchomovsky \& Peter Siegelman, Towards an Integrated Theory of Intellectual Property, 88 VA. L. REV. 1455 (2002).

11 The Internet has profoundly influenced the recent development of trademark jurisprudence and usage. See generally Dan L. Burk, Trademark Doctrines for Global Electronic Commerce, 49 S.C. L. REV. 695 (1998); John M. Carson et al., Claim Jumping on the Newest Frontier: Trademarks, Cybersquatting, and the Judicial Interpretation of Bad Faith, 8 UCLA ENT. L. REV. 27 (2000); Marcelo Halpern \& Ajay K. Mehrota, From International Treaties to Internet Norms: The Evolution of International Trademark Disputes in the Internet Age, 21 U. PA. J. INT'L ECON. L. $523(2000)$. 
foundation of the Paradigm. ${ }^{12}$

This Article contends that the Paradigm's exclusion of trademarks is the result of a legislative reaction that occurred without a proper inquiry into trademark's status as intellectual property, and that the exclusion threatens to bankrupt the goodwill of trademarks. This Article argues that trademark's rapidly evolving role in the Internet economy and in integrated intellectual property licensing calls for an end to the exclusion of trademarks from the Paradigm.

Part I examines the phenomenal rise of trademarks through licensing and the global Internet medium. This Part analyzes how the liberalization of the quality control requirement in licensing arrangements has fostered the expanded role of trademarks in the marketplace.

Part II identifies the Intellectual Property Bankruptcy Paradigm in which patents, copyrights, and trade secrets - but not trademarks - are protected. This Part discusses the enactment of the Intellectual Property Licenses in Bankruptcy Act ("IPLBA"), and argues that Congress passed the Act in reaction to a court decision. Congress claimed that the creation of the IPLBA was necessary to maintain U.S. leadership in technology development. This rationale, however, does not justify the exclusion of trademarks from the Paradigm that protects only patent, copyright, and trade secret licenses. This Part explores the rationale and its limitations by examining, comparing, and contrasting patents, copyrights, trade secrets, and trademarks.

Part III analyzes how notable cases have perpetuated the Paradigm. This Part identifies the consequences of the Paradigm on trademark licenses by examining two cases in which courts have applied the law and extinguished licensees' rights to use licensed trademarks. Canons of statutory construction force courts to perpetuate the Paradigm, and do not permit courts to consider the high cost borne only by licensees of trademarks.

Part IV questions whether the Paradigm's exclusion of trademarks is rational in light of both the increased importance of Internet domain names as trademarks and the integration of trademark licenses as parts of the bundle of licensed rights. This Part focuses on the threat of bankrupting the goodwill of trademarks and its potential threat to the nascent e-commerce economy. This Part examines the consequences that ensue when the licenses of trademarked domain names and the licenses of trademarks in integrated licensing schemes are terminated and

12 See infra Part IV. 
subsequently used by the bankrupt licensor or its authorized third party in association with different web pages, mix-matched, or materially different goods.

Part $\mathrm{V}$ recommends the end of the exclusion of trademarks from the Paradigm. In light of the changing role of trademarks and the integration of trademarks in intellectual property licensing schemes, an amendment to the existing law is appropriate. When Congress enacted the IPLBA, quality control was the rationale for the exclusion of trademarks from the protection provided under the IPLBA. Such concern, however, does not justify the exclusion of trademarks. This Part also proposes and evaluates ways in which the exclusion of trademarks should cease.

The Article concludes that the changing role of trademarks, the integration of trademarks into intellectual property licensing, and the apparent lack of benefits to the bankruptcy estate, unsecured creditors, and consumers, necessitate a shift in the Intellectual Property Bankruptcy Paradigm.

\section{TRADEMARKS, LICENSES, AND PROPERTY}

\section{A. The Rise of Trademarks}

Trademarks are words, phrases, logos, symbols, and devices ${ }^{13}$ that are used in commerce to signify a source and to distinguish the source from others. ${ }^{14}$ The roots of trademark use can be traced back to antiquity ${ }^{15}$ when artisans used marks to identify their pottery. ${ }^{16}$ Traders then

1315 U.S.C. $\$ 1127$ (2000) (defining trademarks).

${ }_{14}$ See Eric J. Lubochinski, Hegel's Secret: Personality and the Housemark Cases, 52 EMORY L.J. 489, 489 (2003) (stating courts have long held that trademarks are source identifiers); Tyler T. Ochoa, Patent and Copyright Term Extension and the Constitution: A Historical Perspective, 49 J. COPYRIGHT SOC'Y U.S.A. 19, 93 (2001) (stating that trademarks must serve as source identifiers, distinguishing "the goods or services of the mark owner from those of others"). Judge Kozinski, however, has suggested that trademarks serve not only as source identifiers, but also as part of the goods or services themselves. Alex Kozinski, Trademarks Unplugged, 68 N.Y.U. L. REV. 960, 972-73 (1993).

15 See Daniel M. McClure, Trademarks and Unfair Competition: A Critical History of Legal Thought, 69 TRADEMARK REP. 305, 310 (1979) ("The earliest use of marks on goods dates to antiquity ...."); Gerald Ruston, On the Origin of Trademarks, 45 TRADEMARK REP. 127, 128 (1955) ("The history of marks is very old indeed. I have seen reproductions of some examples of stone-age pottery bearing marking of perhaps 5,000 B.C.").

${ }_{16}$ BeVERLy W. PATtishall ET Al., TRADEMARKS AND UNFAIR COMPETTTION 1 (1994); see also Amir H. Khoury, Ancient and Islamic Sources of Intellectual Property Protection in the Middle East: A Focus on Trademarks, 43 IDEA 151, 156 n.24 (2003) (noting examples of marks 
marked their wares to distinguish them from goods produced by others. ${ }^{17}$ Cattle raisers branded their animals to identify source and ownership. ${ }^{18}$

Though trademarks have been used for millennia, trademark jurisprudence is relatively young, with origins in the common law system and the 1584 Sandforth's Case in England. ${ }^{19}$ In the United States, the earliest recorded trademark case was in Massachusetts in $1837 .^{20}$ Under the common law of "passing off," the trademark owner sought protection for its trademarks. ${ }^{21}$ In the late nineteenth- and early

affixed on ancient pottery in Transylvania, Greece, Crete, and China).

17 See Graziella M. Sarno, Comment, Viet Nam or Bust: Why Trademark Pirates are Leaving China for Better Opportunities in Viet Nam, 14 DICK. J. INT'L L. 291, 296 (1996) (stating that in Tang Dynasty (618-906 A.D.) traders and merchants marked their goods to distinguish ownership); see also Geoffrey T. Willard, An Examination of China's Emerging Intellectual Property Regime: Historical Underpinnings, the Current System and Prospects for the Future, 6 IND. INT'L \& COMP. L. REV. 411, 413 (1996) (stating that "[t]he first known trademarks surfaced in China nearly 3000 years ago, during the reign of the Zhou Dynasty.").

18 Sidney A. Diamond, The Historical Developments of Trademarks, 65 TRADEMARK REP. 265, 266-67 (1975); see Curtis Nyquist, A Spectrum Theory of Negotiability, 78 MARQ. L. REV. 897, 959 n.390 (1995) (noting that term "ear-mark" referred to "a brand that allowed the owner to reclaim cattle if lost or stolen"); Ruston, supra note 15, at 129 (discussing ear-mark brand on cattle in Madagascar during Stone Age). In Texas, the branding of cattle to signify ownership officially began on July 1,1762 . Robert L. Dabney, Jr., Texas - The Land of the Brave (1518-1821), 39 Hous. LAW. 12, 17 (Apr. 2002).

19 In Sandforth's Case, the plaintiff alleged an action of deceit by the defendant's use of a trademark similar to the plaintiff's mark. The case is discussed in greater detail in Keith M. Stolte, How Early Did Anglo-American Trademark Law Begin? An Answer to Schechter's Conundrum, 8 FORDHAM INTELl. PROP. MEDIA \& ENT. L.J. 505 (1998); see also SHELDON W. HALPERN ET AL., FUnDAMENTALS OF UNITED STATES INTELleCtuAl PROPERTY LAW, COPYRIGHT, PATENT, AND TRADEMARK 276 (1999).

${ }^{20}$ See FRANK H. Foster \& ROBERT L. SHOOK, PATENTS, COPYRIGHTS, \& TRADEMARKS 22 (2d ed. 1993). The earliest appellate court decision concerning trademarks occurred in 1844 in Taylor v. Carpenter, 23 F. Cas. 742 (C.C. Mass. 1844). See also Mark A. Thurmon, Ending the Seventh Amendment Confusion: A Critical Analysis of the Right to a Jury Trial in Trademark Cases, 11 TEX. INTELL. PROP. L.J. 1, 65 (2002).

${ }^{21}$ The history of trademark jurisprudence, as observed by a commentator, is an offshoot of common law tort:

The development of trademark law in America paralleled that of English law. It developed as an offshoot of the tort of fraud and deceit, and was called "passing off." ... confusion was recognized as one basis for trademark suits, the dominant rationale for relief in such cases was 'the promotion of honesty and fair dealings, because no one has a right to use his own goods as the goods of another.' ... The early development of trademark law in America was thus based firmly on notions of morality, focusing on the fraudulent activity of the defendant.

McClure, supra note 15, at 314-15. 
twentieth-centuries, ${ }^{22}$ protection was codified first in the Trademark Acts, ${ }^{23}$ then later in the more comprehensive Lanham Act. ${ }^{24}$

In recent years federal trademark law has expanded to protect trademarks against dilution ${ }^{25}$ and cybersquatting. ${ }^{26}$ Essentially, in addition to protecting against infringement, the trademark owner can protect famous trademarks from tarnishment or blurring use by a third party. ${ }^{27}$ The trademark owner also has a new statutory right against the

${ }_{22}$ As observed by Frank Schechter, the Industrial Revolution profoundly influenced the development of trademarks and trademark jurisprudence:

[T]rade-marks did not develop as valuable symbols of good-will so long as producer and consumer were in close contact.... Close upon the Industrial Revolution came a tremendous expansion not only in the means of production and distribution but, proportionately, in the advertising of goods, in which process trade-marks for the first time acquired a national and not merely local significance.

Frank I. SCHECHTER, THE Historical Foundations of the LaW Relating to TRADEMARKS, 129-30 (1925).

${ }^{23}$ The United States Supreme Court struck down the early Trademark Act as unconstitutional, holding that the Act was beyond the power of Congress to enact under the patent and copyright clause. The Trade-Mark Cases, 100 U.S. 82, 96 (1879). Congress then enacted the federal trademark protection statute under the Commerce Clause. See Xuan-Thao N. Nguyen, Shifting the Paradigm in E-commerce: Move Over Inherently Distinctive Trademarks - The E-Brand, I-Brand and Generic Domain Names Ascending to Power? 50 AM. U. L. REV. 937, 942 n.26 (2001) (noting development of trademark statutes).

Trademark registrations experienced a slow start at the beginning, as observed by Schechter that until " 1870 only sixty-two trade-mark cases in all were decided by American courts. An idea of the growth of the importance of trade-marks to their owners may be gathered from the fact that in 1870 only one hundred and twenty-one trade-marks were registered under the Trademark Act... while in 1923 almost fifteen thousand were registered." SCHECTER, supra note 22, at 134.

${ }_{24}$ See Jean Wegman Burns, Confused Jurisprudence: False Advertising Under the Lanham Act, 79 B.U. L. Rev. 807, 811-16 (1999) (analyzing legislative and social history of Lanham Act); Roberta Rosenthal Kwall, The Attribution Right in the United States: Caught in the Crossfire Between Copyright and Section 43(a), 77 WASH. L. REV. 985, 1003 (2002) (stating that Lanham Act was enacted to codify common law trademark doctrine of "passing off" representation of defendant's goods as those of plaintiff).

The Lanham Act was enacted in 1946. William M. Landes \& Richard A. Posner, Trademark Law: An Economic Perspective, 30 J.L. \& ECON. 265, 269-70 (1987) (analyzing legislative history of Lanham Act and stating that rationales for trademark protections were to reduce consumer search costs and to encourage producers to make high quality products); see also S. Rep. No. 79-1333, at 3 (1946), reprinted in 1946 U.S.C.C.A.N. 1274, 1274.

${ }_{25}$ See Federal Trademark Dilution Act of 1995, Pub. L. No. 104-98, 109 Stat. 987 (1995) (codified as amended at 15 U.S.C. $\S 1125(c)(2000)$ ).

${ }_{26}$ See Anticybersquatting Consumer Protection Act, Pub. L. No. 106-113, 113 Stat. 1501 (1999) (codified as 15 U.S.C. $§ 1125(d)(2000)$ ).

27 See Jason R. Edgecombe, Comment, Off the Mark: Bringing the Federal Trademark Dilution Act in Line With Established Trademark Law, 51 EMORY L.J. 1247, 1253-56 (2002) (summarizing trademark dilution under tarnishment and blurring theories); Katherine 
unauthorized registration of trademarks as Internet domain names. ${ }^{28}$

Through years of expansive use, advertisement, and enforcement, ${ }^{29}$ some trademarks have become known worldwide and are very valuable corporate assets. ${ }^{30}$ For example, it is estimated that the Marlboro mark is worth $\$ 44.6$ billion, the Coca-Cola mark over $\$ 43$ billion, and the McDonald's mark nearly $\$ 19$ billion. $^{31}$ The owner of a trademark has the right to reap the financial reward from the goodwill it has established in association with the trademark, and the law protects the owner from those who poach that goodwill. ${ }^{32}$

With these legal rights protecting valuable trademarks, the trademark owner can maximize its position in the marketplace. One of the most common methods of trademark expansion in the marketplace is

Ruwe, Comment, The Federal Trademark Dilution Act: "Actual Harm" or "Likelihood of Dilution"?, 70 U. CIN. L. REV 1175, 1178-91 (2002) (analyzing federal circuit courts' conflicting decisions on standard of proof for dilution).

${ }_{28}$ See Dara B. Gilwit, Note, The Latest Cybersquatting Trend: Typosquatters, Their Changing Tactics, and How to Prevent Public Deception and Trademark Infringement, 11 WASH. U. J.L. \& POL'Y 267, 280-32 (2003) (stating that new statute assists trademark owners in combating cybersquatters); cf. Suzanna Sherry, Haste Makes Waste: Congress and the Common Law in Cyberspace, 55 VAND. L. REV. 309, 320 (2002) (arguing that anti-cybersquatting consumer protection act was unnecessary because federal trademark dilution act alone can curb cybersquatting).

${ }^{29}$ Brendan Mahaffey-Dowd, Famous Trademarks: Ordinary Inquiry by the Court of Marks Entitled to an Extraordinary Remedy, 64 BROOK. L. REV. 423, 425 (1998) (noting that "[o]wners of famous marks typically spend millions of dollars to promote the mark and to create an instant association between that mark and the product in the minds of consumers."). Companies like Proctor \& Gamble, General Motors, and Phillip Morris spend billions of dollars annually to advertise and promote their trademarks. Id. at $425 \mathrm{n} .15$ (stating that Proctor \& Gamble spent $\$ 2.6$ billion in 1996, General Motors $\$ 2.37$ billion, and Phillip Morris $\$ 2.28$ billion on advertising and promoting their brands).

${ }^{30}$ After years of building the goodwill in a trademark, the owner can sell, license, or assign the trademark to a third party for monetary exchange. The value of a trademark right can be quite significant. See, e.g., United Drug Co. v. Parodney, 24 F.2d 577, 579 (E.D.N.Y. 1928) ("[T]heoretically and perhaps practically as well, this hard-earned right is as important as money in the bank.").

${ }^{31}$ Mahaffey-Dowd, supra note 29 , at $425 \mathrm{nn} .15$ \& 17.

32 "The protection of such monopolies in names seems, then, to rest on the social interest in protecting primarily, not the consumer, but the businessman who has gained a strategic advantage, through building up of good-will, against unfair practices by competitors who desire to poach on this good-will." E. Wine Corp. v. Winslow-Warren, Ltd., 137 F.2d 955, 958 (2d Cir. 1943), cert. denied, 320 U.S. 758 (1943); see Qualitex Co. v. Jacobson Prods. Co., 514 U.S. 159, 164 (1995) (stating that trademark law aims to assure producers that they will be able to "reap the financial, reputation-related rewards" of their product); United States v. Hon, 904 F.2d 803 (2d Cir. 1990), cert. denied, 498 U.S. 1069 (1991) (stating that trademark law protects "the trademark owner's investment in the quality of the mark and his product's reputation," purpose that is "independent of the goal of preventing consumer deception"). 
licensing. ${ }^{33}$

\section{B. Trademark Licensing and Quality Control}

A trademark license is a grant of a specified right to use the trademark in connection with particular goods or services, in a field of use, ${ }^{34}$ and within a geographic area. ${ }^{35}$ A license can be exclusive or non-exclusive ${ }^{36}$ with respect to field of use and geography.

Trademark licensing is a common practice today. ${ }^{37}$ Prior to the 1946 enactment of the Lanham Act, trademark licensing was restricted as courts held that trademark licensing without a transfer of business assets amounted to abandonment of the trademark. ${ }^{38}$ The enactment of the

${ }^{33}$ See generally Jack Russo, Why License? Business Strategies for "Win/Win" Agreements, 458 PLI/Pat 201 (1996); Linda J. Soranno, The Business and Legal Fundamentals of Corporate Licensing, 534 PLI/Pat 127 (1998).

${ }^{34}$ See Lisa Keyes \& Amanda Nyes, Fundamentals of Trademark Licensing, 733 PLI/Pat 7, 15-16 (2003) (stating that "field of use" is essentially on "what products or services the trademarks may be used"); see also Michael Fawlk, Trademark Delimitation Agreements Under Article 85 of The Treaty of Rome, 82 TRADEMARK REP. 223, 226 (1992) (stating that restrictions on use of trademark in relation to goods and/or services is called "field of use restrictions").

${ }^{35}$ George J. Alexander, Competing in Global Product Innovation: Is Antitrust Immunity Necessary?, 6 SANTA ClARA COMPUTER \& HIGH TECH. L.J. 147, 158 (1991) ("[A]s a general matter, trademark owners can license exclusive territories for their use."); Fawlk, supra note 34 , at 226 (stating that restrictions on use of trademark in certain geographic areas are "territorial restrictions").

${ }^{36}$ An exclusive licensee may have a standing to sue under trademark law. Ultrapure Sys., Inc. v. Ham-Let Group, 921 F. Supp. 659 (N.D. Cal. 1995); Susan Progroff, Trademark Licensing, 722 PLI/Pat 13, 28-29 (2002), citing Quabaug Rubber Co. v. Fabiano Shoe Co., 567 F.2d 154 (1st Cir. 1977). Both exclusive and non-exclusive licensees have "standing to assert a claim of unfair competition under Section 43(a) of the Lanham Act, 15 U.S.C. § 1125 (a), which provides that an action may be brought by 'any person who believes that he or she is or is likely to be damaged' by the acts of unfair competition." Progroff, supra, at 29.

Trademark law permits exclusive licensees to register the licensed trademarks. 15 U.S.C. $\S 1056(2000)$. The registration of the trademarks must be in the name of the trademark owner and all uses of the registered trademark by the licensee inures exclusively to the benefits of the trademark owner. Id. $\S \S 1052,1056,1127$.

${ }^{37}$ See Russo, supra note 33, at 204-05 (discussing business trends favoring licensing); Soranno, supra note 33 , at 131 (stating that as trademarks become valuable corporate assets, companies embark on licensing programs to reap benefits of trademark assets).

38 See Alfred M. Marks, Trademark Licensing - Towards a More Flexible Standard, 78 TRADEMARK REP. 641, 642 (1988) (stating that trademark licensing was prohibited, "except as incidental to a transfer of the business or property in connection with which it has been used" (quoting MacMahan Pharmacal Co. v. Denver Chem. Mfg. Co., 113 F. 468, 474-75 (8th Cir. 1901))); see, e.g., Reddy Kilowatt, Inc. v. Mid-Carolina Elec. Coop., 240 F 2d 282, 289 (4th Cir. 1957). 
Lanham Act legalized trademark licensing, ${ }^{39}$ paving the way for extensive trademark licensing. ${ }^{40}$ Trademark licensing facilitates national and global commerce and the exploitation of trademarks through more complex licensing programs such as franchising ${ }^{41}$ and character licensing. ${ }^{42}$

A trademark owner may decide to license its trademarks for a number of reasons. ${ }^{43}$ The trademark owner can gain revenue from royalty fees without the need to engage in the manufacture or marketing of the products. ${ }^{44}$ The trademark owner can broaden its reach to different

39 Robert P. Merges, One Hundred Years of Solitude: Intellectual Property Law, 1900-2000, 88 CAL. L. REV. 2187, 2211 (2000) (stating that Lanham Act clarified that trademark licensing was "perfectly lawful activity").

40 Professor Merges, in his review of the development of intellectual property law, keenly observes:

[The] liberalization of trademark licensing had very important consequences for twentieth-century commerce. In particular, secure trademark licensing helped usher in two important commercial practices with significant economic repercussions: (1) national franchising, and (2) so-called character and merchandise licensing.

Id. at 2212.

4 See Deborah S. Coldwell, et al., Franchise Law, 55 SMU L. REV. 1075, 1106 (2002) (stating that franchising involves intellectual property rights such as trademarks, trade names, proprietary system of operation, and trade dress).

12 Character merchandising is a type of licensing wherein the characters are used in connection with products and services. See Jay S. Kogan, Character Licensing, 692 PLI/Pat 223, 229 (2002). The history of character merchandising begins in the early twentieth century:

Beginning in the early twentieth century with characters from comic strips such as Buster Brown and Mutt and Jeff, followed by the characters from comic books such as Superman and Batman, animation characters like Mickey Mouse, and radio characters like the Lone Ranger, and gradually but continually expanding thereafter with major growth from the 1970s forward with the blockbuster movies accompanied by merchandising tie-ins exemplified by the Star Wars phenomenon, characters have developed into one of the most valuable sources for licensing and merchandising. Characters are now licensed for use in connection with nearly every conceivable media, product, and service.

Id.; see also Jessica Litman, Mickey Mouse Emeritus: Character Protection and the Public Domain, 11 U. MIAMI ENT. \& SPORTS L. REV. 429, 432-33 (1994) (critiquing expansive protection under Lanham Act for characters).

${ }^{43}$ See Russo, supra note 33, at 207-11 (analyzing range of benefits flowing from licensing programs); Soranno, supra note 33 , at 131-34 (discussing numerous benefits gained by trademark licensor through licensing practices).

${ }^{44}$ See Russo, supra note 33, at 207 (stating financial benefit as primary reason for licensing); Soranno, supra note 33, at 131-32 (stating that through licensing, trademark owner "gains entry into markets that may not be readily accessible to it, ... assigns risk of product development to an outside organization,... shares the cost of advertising and 
fields of use and different markets through licensing programs. ${ }^{45}$ Trademark licensing allows the trademark owner to build and enhance the goodwill of the trademark through the licensee's use of the trademark, without the trademark owner's actual use of the trademark in the marketplace. ${ }^{46}$

A trademark owner may choose to use the trademark on some of its products and to license the right to use the mark for other goods and services to a third party, particularly where the trademark owner has little or no manufacturing or marketing expertise in the area of the licensed products. ${ }^{47}$ For example, the owner of the television show The Simpsons may want to capitalize on the popularity of the show by granting the right to use the Simpsons trademark to various companies for use on clothing, toys, cereals, snacks, school supplies, and similar products. $^{48}$ Typically, a trademark owner uses a licensing agent to manage the licensing program. ${ }^{49}$

promoting the trademark, ... and ... enhances earnings through royalty income").

${ }^{45}$ See Keyes \& Nyes, supra note 34, at 19 (stating that licensor can grant licensee right to establish new brand by use of licensed trademark in new field of use).

${ }^{46}$ See 2 STEPHEN P. LADAS, PATENTS, TRADEMARKS AND RELATED RighTS 1127 (1975) (stating that licensing to unrelated third party yields greater profitability).

${ }^{47} \mathrm{~J}$. Allison Strickland, Fundamentals of Trademark and Copyright Licensing, 741 PLI/Pat 275,277 (2003).

48 See Mathew D. Caudill, Beyond the Cheese: Discerning What "Causes Dilution" Under 15 U.S.C. 1125(c) - A Recommendation to Whittle Away the Liberal Application of Trademark Dilution to Internet Domain Names, 13 Fordham INTEL. Prop. MEdiA \& ENT. L.J. 231, 264 (2002) (noting that Warner Brothers expands trademark Road Runner for use in connection with high speed Internet service and numerous merchandising items); Cheryl $M$. Friedman, Trademark Protection of Motion Pictures, Merchandising Items, and Television Programs in the Republic of China, 13 LoY. L.A. INT'L \& COMP. L.J. 36, 37 (1990) (stating that in entertainment industry, trademarked product may be "anything from an item of merchandise sold in connection with a feature film or television show, to the name of the film or show itself").

A merchandising right may be quite extensive. For example, the merchandising right for Toy Story, may be defined as:

the right to make, use, sell, exercise or otherwise exploit and license or authorize others to make, use, sell, exercise or otherwise exploit tangible personal property, of any and all kinds, based upon, utilizing or embodying ... Toy Story, or any of the characters or story or other unique elements thereof, including without limitation any unique names, likenesses or characteristics of any character portrayed therein other than pre-existing Disney characters, or any unique title, catch word, slogan, situations, designs, equipment or events depicted therein, or any trademark, trade name or copyright related thereto other than pre-existing Disney marks.

Joseph Yang et al., Sample Complex Content Agreement, 736 PLI/Pat 531, 541-42 (2003).

49 Soranno, supra note 33, at 138 (stating that many companies use third party licensing 
Intellectual property owners also license trademarks in connection with the licensing of copyrighted works, particularly in the case of character merchandising. ${ }^{50}$ For example, Tarzan, Superman, Mickey Mouse, ${ }^{51}$ Yogi Bear, and The Flintstones licenses involve both copyrighted works and trademarks. ${ }^{52}$ Likewise, some software licenses involve both copyrighted computer programs and the trademarks associated with the software programs. ${ }^{53}$

agents to manage and administer their licensing programs); see Kristine A. Brown, Native American Team Names and Mascots: Disparaging and Insensitive Or Just a Part of the Game?, 9 SPORTS LAW. J. 115, 123 (2002) (noting that in professional sports industry, many leagues "have been so successful in marketing their teams' trademarks that they have created exclusive licensing agents such as NFL Properties, Major League Baseball Properties, NBA Properties, and the Licensing Company of America").

50 See Strickland, supra note 47, at 279 (discussing license of copyrights in conjunction with trademarks in character merchandising).

${ }^{-51}$ See Leslie A. Kurtz, The Independent Legal Lives of Fictional Characters, 1986 WIS. L. REV. 429, 474-77 \& n.259 (1986) (analyzing copyright and trademark protections for characters such as Tarzan, Superman, and Mickey Mouse).

${ }^{52}$ See Strickland, supra note 47 , at 279 (providing examples of character merchandising).

${ }^{53}$ See, e.g., In re Centura Software Corp., 281 B.R. 660, 673 (Bankr. N.D. Cal. 2002). Many software companies include in the end user license agreement a provision asserting their copyright, patent, trade secrets, and trademark rights in the software. Daniel C. Miller, Note, Determining Ownership in Virtual Worlds: Copyright and License Agreements, 22 REV. LITIG. 435, 438 (2003). Licensees of software usually would like to have in a software license agreement a warranty of rights such as:

Licensor represents and warrants that it has all rights necessary to license the Licensed Software to Licensee pursuant to this Agreement and that Licensee's use [and distribution] of the Licensed Software in accordance with this Agreement will not infringe any third party's patents, copyrights, trade secret rights, trademarks, or other intellectual property or proprietary rights of any nature.

Eric M. Reifschneider \& Barbara A. Walkowski, Warranty, Indemnification, and Limitation of Liability Provisions in Software License Agreements, 1356 PLI/Corp 741, 757 (2003).

In recent years, patent protection for computer software has become available if a computer-related method claim produces a "useful, concrete and tangible result." State St. Bank \& Trust Co. v. Signature Fin. Group, Inc., 149 F.3d 1368, 1373 (Fed. Cir. 1998). See generally AT\&T Corp. v. Excel Communications, Inc., 172 F.3d 1352 (Fed. Cir. 1999). 
A franchise is a type of complex trademark license. ${ }^{54}$ In certain industries such as hotel, ${ }^{55}$ fast food, ${ }^{56}$ or clothing, ${ }^{57}$ the trademark owner establishes market penetration through franchising rather than engaging

s4 See Michael J. Lockerby, Revisionist History? Kicking the Tires of J. Michael Dady's Market Withdrawal Cases, 21 FRANCHISE L.J. 177, 217 n.112 (2002) (noting that some states define franchise in terms of trademark licenses). For example, the Arkansas Franchise Practices Act defines "franchise" as:

a written or oral agreement for a definite or indefinite period, in which a person grants to another person a license to use a trade name, trademark, service mark, or related characteristic within an exclusive or nonexclusive territory, or to sell or distribute goods or services within an exclusive or nonexclusive territory, at wholesale, retail, by lease agreement, or otherwise.

Id.; see also Philip F. Zeidman, Franchising and Other Methods of Distribution: Regulatory Pattern and Judicial Trends, 1355 PLI/Corp 1071, 1085 (2003). Zeidman states:

"Franchise" means a contract or agreement, either expressed or implied, whether oral or written, between two or more persons by which: (1) A franchisee is granted the right to engage in the business of offering, selling or distributing goods or services under a marketing plan or system prescribed in substantial part by a franchisor; and (2) The operation of the franchisee's business pursuant to such plan or system is substantially associated with the franchisor's trademark, service mark, trade name, logotype, advertising or other commercial symbol designating the franchisor or its affiliate; and (3) The franchisee is required to pay, directly or indirectly, a franchise fee.

Id.

55 A typical franchise agreement includes the license of trademarks to be used in the franchise. See Joseph Philip Forte, Franchisor Comfort Letter, 446 PLI/Real 705, 707 (1999) (listing trademark license in franchise agreement); Jonathan Solish et al., Franchising Currents, 14 FRANCHISE L.J. 105, 105 (1995) ("Hospitality Franchise Systems owns the franchising and trademark licensing rights to Days Inns, Ramada, Howard Johnson, Super 8, and Park Inns, which together make up approximately twenty-five percent of the domestic hotel franchising market."). When a franchise is terminated, but the franchisee still continues to use the licensed trademark, the franchisor can initiate a trademark infringement action against the franchisee. See, e.g., Choice Hotels Int'l. Inc. v. Pennave Assocs., 159 F. Supp. 2d 780 (E.D. Pa. 2001) (awarding fees where defendant franchisee continued to make use of mark Clarion Hotel after franchisor sent several cease and desist letters and issued notice of termination of hotel franchise agreement).

56 See Bethany L. Appleby, Interim Relief: Preserving Franchising Goodwill During Termination Proceeding, 22 FRANCHISE L.J. 125, 126 (2002) (analyzing subject matter of typical fast-food restaurant franchise agreement with respect to termination arbitration). An example is a case where the franchisee of a fast-food restaurant is in bankruptcy. See In re Sunrise Rest., Inc., 135 B.R. 149 (Bankr. M.D. Fla. 1991) (holding that franchise agreement was transferable, despite anti-assignment clause in agreement, because arrangement was not one involving special task, skill, or ability on franchisee's part).

57 See Erin Ann O'Hara, Opting Out Regulation: A Public Choice Analysis of Contractual Choice of Law, 53 VAND. L. REV. 1551, 1591 (2000) (stating that fast food restaurants, clothing and shoe stores, convenience stores, and car rentals are among more well-known franchise businesses). 
in self-operation. ${ }^{58}$ Under a franchise arrangement, the franchisor grants the franchisee the right to engage in the franchisor's business bearing the franchisor's trademark in exchange for a franchise fee. ${ }^{59}$

Whether a trademark arrangement is a simple license or a complex franchise agreement, the quality control of the use of the trademark is an important issue. A trademark license is deemed "uncontrolled" or "naked" if the licensor fails to maintain adequate control over the quality of the uses of the trademark. ${ }^{60}$ Uncontrolled use may be deemed an

${ }^{58}$ See Frank J. Cavico, "Extraordinary or Specialized Training" as a "Legitimate Business Interest" in Restrictive Covenant Employment Law: Florida and National Perspectives, 14 ST. THOMAS L. REv. 53, 92-95 (2001) (analyzing number of cases involving retail franchising of goods and services).

59 Typical in its approach to these arrangements, the Minnesota Franchise Law defines a franchise as including:

(1) a contract or agreement, either express or implied, whether oral or written, for a definite or indefinite period, between two or more persons:

(i) by which a franchisee is granted the right to engage in the business of offering or distributing goods or services using the franchisor's trade name, trademark, service mark, logotype, advertising, or other commercial symbol or related characteristics;

(ii) in which the franchisor and franchisee have a community of interest in the marketing of goods or services at wholesale, retail, by lease, agreement, or otherwise; and

(iii) for which the franchisee pays, directly or indirectly, a franchise fee

Minn. Stat. § 80C.01 (2000). See generally Lockerby, supra note 54, at 217 n.112.

so The Lanham Act allows licensing of trademarks as long as the licensor maintains quality control:

Where a registered mark or a mark sought to be registered is or may be used legitimately by related companies, such use shall inure to the benefit of the registrant or applicant for registration, and such use shall not affect the validity of such mark or of its registration, provided such mark is not used in such manner as to deceive the public.

15 U.S.C. $§ 1055$ (2000).

The term "related company" means any person whose use of a mark is controlled by the owner of the mark regarding the nature and quality of the goods or services on or in connection with which the mark is used. Id. $\S 1127$.

${ }^{61}$ The quality control requirement embraced by courts and commentators has been challenged as lacking legal and practical foundations. Kevin Parks, "Naked" Is Not a FourLetter Word: Debunking the Myth of the "Quality Control Requirement" in Trademark Licensing, 82 TRADEMARK REP. 531 (1992). The commentator identified the fundamental problem with the quality control requirement as its "inconsistent treatment of licensing and non-licensing trademark owners." Id. at 536. In a licensing situation, if the trademark owner fails to exercise quality control, trademark licensing would create the danger that products bearing 
abandonment of the trademark by the owner. The purported reason for the quality control requirement in trademark licensing is to protect the consumer from confusion and deceit. ${ }^{61}$ In recent years, courts have less rigorously applied the quality control requirement, and have been more willing to find sufficient quality control in licensing arrangements where "there were no written standards available to be used during inspection of the licensee, no written reports documenting alleged inspections by licensor's representatives, and no evidence that the licensee had a quality control program which the licensor could rely on. ${ }^{162}$ With the relaxation of the quality control requirement, the trademark owner can satisfy the quality control requirement by choosing numerous available means to maintain either direct or indirect control of the licensees' use of the licensed trademarks. ${ }^{63}$

\section{Trademarks and the Internet}

The Internet has become a powerful medium of global communication and commerce. ${ }^{64}$ There are more than 650 million users worldwide ${ }^{65}$ and

the same trademark might be of diverse quality. Id. But in "an ordinary non-licensing situation, the trademark owner has no duty to prevent diversity in the quality of the goods bearing his trademark." Id. (quoting William R. Woodward, Some Observations on Legitimate Control of the Nature and Quality of the Goods, 49 TRADEMARK REP. 609, 611 (1959)).

${ }_{62}$ Elizabeth C. Bannon, The Growing Risk of Self-Dilution, 82 TRADEMARK REP. 570, 578 (1992).

${ }^{63}$ Under direct control, as suggested by a commentator, the trademark licensor may choose one or more of the following:

a. Supplying proper use guidelines to licensees, such as "style guides" or creating the actual artwork to be used: the advent of computer graphic files and downloading from the Internet or a network makes this a simple methodology that is easy to control;

b. Actual supply of products or ingredients, or in the case of services, management and technical assistance;

c. Approving samples, etc. at various stages of design and manufacture;

d. Visiting licensee's facilities and/or approving sublicensees and contract manufacturers chosen by the licensee;

e. Reviewing quality control tests; and

f. Acting on consumer/user complaints

Steven M. Weinberg, Overview of the Law and Business of Licensing Intellectual Property in 2002, 629 PLI/Pat 9, 18-19 (2002).

Under indirect control, the trademark owner may delegate the responsibility to an independent agent that is not the licensee or appoint the licensee as the quality control agent. Id. Courts have upheld indirect control practice in cases where the licensor is not familiar with or has no experience in the manufacturing and marketing of the licensed products. Id. (citing Winnebago Indus., Inc. v. Oliver \& Winston, Inc., 207 U.S.P.Q. 335 (TTAB 1980)).

64 A. Michael Froomkin, Habermas@discourse.net: Toward a Critical Theory of Cyberspace, 
more than one billion publicly readable web pages available on the rapidly evolving Internet. ${ }^{66}$ Presently, in the .com Top-Level-Domain $($ "TLD") alone, there are more than twenty-three million active domain names.

Domain names are the easily remembered version of the complex numerical Internet Protocol addresses. ${ }^{68}$ Domain names were introduced to facilitate and encourage Internet use. ${ }^{69}$ They link users to the global communication and commerce network. ${ }^{70}$

116 HARV. L. REV. 749, 782 (2003) ("What had once been the preserve of computer science and electrical engineering departments, and of computer nerds, now raises legal, social, and commercial policy questions ranging from pricing to privacy.").

${ }^{65}$ Global Reach provides global Internet statistics on population and language. See http://www.global-reach.biz/globstats/ (last visited Mar. 4, 2004); see also www.nua.com/surveys/how_many_online/index.html (reporting that as of September 2002 there were 605.6 million users worldwide). In the United States, more than 72 percent of Americans are on the World Wide Web. Hugh Calkins, Maine Lawyer Websites: The Good, the Bad and the Ugly, 18 ME. BAR J. 78, 79 (2003). Further, about 60 percent of the U.S. population use the Internet. Id.

66 See Froomkin, supra note 64, at 782 (noting growth of web pages and Internet data traffic worldwide).

67 See Whois Source, Detailed Domain Counts and Internet Statistics, at www.whois.sc/internet-statistics/ (providing chart of daily domain statistics in several TLDs) (last visited Mar. 4, 2004).

${ }_{68}$ Stacey H. King, The "Law That It Deems Applicable": ICANN, Dispute Resolution, and the Problem of Cybersquatting, 22 HASTINGS COMM. \& ENT. L.J. 453, 457-58 (2002). The domain name is described as follows:

In order for these networks to communicate with one another, every computer linked to another has a numeric address assigned to it. This number is similar to a telephone number, and other computers use this number to route messages to it. The number, for example 123.456.789.23, is called an Internet Protocol, or IP address. These IP addresses are, due to their length, often hard to remember, particularly as the Internet has grown and the number of computers and commercial sites linked to the Internet have also expanded.

Id.; see also Jennifer Dupre, A Solution to the Problem? Trademark Infringement and Dilution by Domain Names: Bringing Cyberworld in Line with the "Real" World, 87 TRADEMARK REP. 613, 614 (1997) (describing domain names).

69 Each computer connected to the Internet is often referred to as a "host" or "hosts." As of January 1, 2003, there are about 171,638,297 hosts worldwide. Internet System Consortium, Internet Domain Survey, at http://www.isc.org/ (last visited Mar. 4, 2004). To facilitate the communications among hosts, each host is assigned a numerical Internet Protocol address that contains four groups of numbers separated by decimals. Since Internet users find it difficult to remember complex numerical addresses, the Domain Name System was introduced to assign alphabetical values to the numbers. See generally Zohar Efroni, The Anticybersquatting Consumer Protection Act and the Uniform Dispute Resolution Policy: New Opportunities for International Forum Shopping? 26 COLUM.-VLA J.L \& ARTS 335, 336 (2002).

${ }^{70}$ See generally Dupre, supra note 68, at 614; Efroni, supra note 69, at 336; King, supra note 68 , at $457-58$. 
A company wishing to establish its presence in the Internet to offer goods, products, or services, must register its website's domain name. ${ }^{71}$ To register a domain name, a company must first determine under which TLD the domain name should be registered. ${ }^{72}$ There are numerous TLDs, but the most popular is the .com TLD. ${ }^{73}$ If a third party has already registered the domain name, the company may choose a different domain name in the same TLD or register its original domain name in a different TLD. ${ }^{74}$

A company that owns protected trademarks may register its trademarks as domain names in an attempt to reach the Internet audience. $^{75}$ In fact, users often search for Internet companies by using trademarks or company names. ${ }^{76}$ An Internet company that does not own any trademark at the outset may seek protection for its domain names under trademark law by registering domain names as trademarks with the United States Trademark Office."

${ }_{11}$ Jeffrey J. Look, Law and Order on the Wild, Wild West (WWW), 24 U. ARK. LITTLE ROCK L. REv. 817, 844 (2002) (stating that start-up companies built their Internet presence through having simple, highly descriptive domain names); Neil Batavia, Comment, That Which We Call a Domain by Any Other Name Would Smell As Sweet: The Overbroad Protection of Trademark Law As It Applies to Domain Names on the Internet, 53 S.C. L. REV. 461, 464 n.35

(2002) ("Domain names offer a global presence on the Internet.").

7 See generally New TLD Program, ICANN, at http://www.icann.org/tlds (last visited Mar. 4, 2004). In the 1980s, seven TLDs (.com, .edu, .gov, .int, .mil, .net, and .org) were created and domain name registrations were permitted in .com, net, and .org without restriction. Seven more TLDs were introduced in 2001 and 2002. They are .biz, info, .name, .pro, .aero, .coop, and .museum. Id.

${ }_{3}$ Jay P. Kesan \& Rajiv C. Shah, Fool Us Once Shame on You - Fool Us Twice Shame on Us: What We Can Learn From the Privatizations of the Internet Backbone Network and the Domain Name System, 79 WASH. U. L.Q. 89, 198 (2001) (stating that popular .com TLD is overcrowded); Elizabeth G. Thornburg, Going Private: Technology, Due Process, and Internet Dispute Resolution, 34 U.C. DAVIS. L. REV. 151, 159 n.27 (2000) (noting that there are over two hundred country code TLDs, but only seven generic TLDs). Of these seven, .com is among the most popular. Id.

${ }_{74}$ See Puneet Singh, Gateway Pages: A Solution to the Domain Name Conflict?, 91 TRADEMARK REP. 1226, 1235 (2001) (noting that under Domain Name System, Aquarius Haircuts cannot register its desired domain name "aquarius" in .com TLD and is forced to choose another domain name such as "aquarius.net" or "aquariushair.com").

75 See Gilwit, supra note 28, at 267 (stating that "using trademarks as domain names helps businesses to create a strong presence on the Internet.").

${ }_{76}$ See Daniel Janis, Internet Domain Names and the Lanham Act: Broadening Trademark Definitions and Their Implications for Speech on the Web, 25 COLUM.-VLA J. L. \& ARTS 21, 35-36 (2001) (discussing common practice by Internet companies who register trademarks as domain names to assist users to reach companies' websites); Tamarah Belczyk, Note, Domain Names: The Special Case of Personal Names, 82 B.U. L. REv. 485, 491 (2002) (commenting that Internet users often search for web site by entering name or trademark followed by .com).

$\pi$ See Deborah Howitt, War.Com: Why The Battles Over Domain Names Will Never Cease, 
As a domain name, however, the life of the protected trademark is dependent on the term of the domain name registration. ${ }^{78}$ A domain name can be registered for one, two, five, or ten years. ${ }^{79}$ The term of domain name registration is unregulated. ${ }^{80}$ When a registration expires, others may register the domain name. ${ }^{81}$ In such cases, the domain name passes to the third-party registrant, and the original trademark owner's use of the domain name must cease. If the original trademark owner wishes to protest the transfer, he or she must resort to international arbitration $^{82}$ or litigation. ${ }^{83}$ The original owner can retrieve the domain

19 HASTINGS COMM. \& ENT. L.J. 719, 731 (1997) (analyzing trademark registration for domain names with Patent and Trademark Office as long as domain names meet trademark requirements); see also Yasaman Navai, Note, Sporty's Farm L.L.C. v. Sportsman Market Inc. - Protecting Against Cybersquatting or Extending the Allowable Reach of Trademark Law on the World Wide Web, 11 DEPAUL-LCA J. ART \& ENT. L. \& POL'Y 191, 195 (2001) (noting that if Internet company obtains trademark registration for its domain name prior to receiving cease and desist letter by third party trademark owner, Internet company may continue to maintain its domain name).

The Patent and Trademark Office considers a domain name a trademark when it serves as a "source identifier' for services that are being offered on the Internet." Lois R. Lupica, The Technology-Rich "Dot-Com" in Bankruptcy: The Debtor as Owner of Intellectual Property, 53 ME. L. REV. 361, 379 (2001) (referring to Patent and Trademark Office, Examination Guide No. 2-99 (Sept. 29, 1999)).

78 Registral.com, LLC v. Fisher Controls Int'l, Inc., No. H-01-1423, 2001 U.S. Dist. LEXIS 10002 (S.D. Tex. June 28, 2001) is illustrative. Fisher Controls had registered numerous trademarks and had operated under the Fisher name since the 1880s. Fisher Controls registered the domain name Fisher.com, but subsequently allowed the domain name registration to lapse. Registral.com registered the Fisher.com domain name two minutes after it was made available to the public for registration. Fisher Controls later attempted to obtain the domain name back through litigation. Id.

To avoid domain name registration lapse, Internet companies are advised to periodically check registrations and calendar the expiration dates. Scott A. Bearby, Marketing, Protection and Enforcement of NCAA Marks, 12 MARQ. SPORTS L.J. 543, 545 (2002).

79 See, e.g., Lockheed Martin Corp. v. Network Solutions, Inc., 985 F. Supp. 949, 953 (C.D. Cal. 1997) (noting NSI charges initial two-year registration fee, and annual charges starting in third year), aff d, 194 F.3d 980, 981 (9th Cir. 1999); Network Solutions, Inc. v. Umbro Int'l, Inc., 529 S.E.2d 80, 84 n.10 (Va. 2000) (noting domain name registrant can obtain domain names for up to 10 years).

so See, e.g., Benjamin B. Cotton, Comment, Prospecting or Cybersquatting: Registering Your Name Before Someone Else Does, 35 J. MARSHALl L. REV. 287, 292-93 (2002) (explaining that domain name registration is on first-come, first-serve basis, and that there is no regulation of domain name registration except requirement to be bound by Uniform Dispute Resolution Policy).

${ }^{81}$ A. Michael Froomkin \& Mark A. Lemley, ICANN and Antitrust, 2003 U. ILL. L. REV. 1,65 (2003) (stating that there is market for domain names that have expired and are not renewed).

${ }^{82}$ See generally Michael Geist, Fair.com?: An Examination of the Allegations of Systemic Unfairness in the ICANN UDRP, 27 BROOK. J. INT'L. L. 903 (2002); Pamela Segal, Attempts to Solve the UDRP'S Trademark Holder Bias: A Problem That Remains Unsolved Despite the Introduction of New Top Level Domain Names, 3 CARDOZO ONLINE J. CONFLICT. RESOL. 1 
name upon proof that the registrant registered the domain name in bad faith. ${ }^{84}$

A trademark in the form of a domain name registration may be characterized as either a license, ${ }^{85}$ a service contract, ${ }^{86}$ or intangible property that is neither merged in, nor identified with, some document. ${ }^{87}$ The prevailing view today on domain name classification is that domain names are intangible property that can be sold, assigned, and transferred. $^{88}$ Domain names can be used as collateral property in

(2001); Lisa M. Sharrock, The Future of Domain Name Dispute Resolution: Crafting Practical International Legal Solutions From Within the UDRP Framework, 51 DUKE L.J. 817 (2001).

83 See generally Adam Silberlight, Domain Name Disputes Under the ACPA in the New Millennium: When is Bad Faith Intent to Profit Really Bad Faith and Has Anything Changed With the ACPA's Inception?, 13 FORDHAM INTELL. PROP. MEDIA \& ENT. L.J. 269 (2002); Jian Xiao, The First Wave of Cases Under the ACPA, 17 BERKELEY TECH. L.J. 159 (2002).

84 See generally Registral.com, LLC v. Fischer Controls Int'l, Inc., No. H-01-1423, 2001 U.S. Dist. LEXIS 10002 (S.D. Tex. June 28, 2001) (holding that domain name registrant obtained domain name in bad faith in violation of Anticybersquatting Consumer Protection Act).

${ }_{85}$ Francis G. Conrad, Dot.coms in Bankruptcy Valuations Under Title 11 or www.snipehunt in the Dark.noreorg/noassets.com, 9 AM. BANKR. L. INST. REV. 417, 430 (2001) (analyzing domain names as licenses).

${ }_{86}$ See, e.g., Dorer v. Arel, 60 F. Supp. 2d 558 (E.D. Va. 1999); Network Solutions, Inc. v. Umbro Int'l, Inc., 529 S.E.2d 80 (Va. 2000).

${ }_{87}$ Kremen v. Cohen, 99 F. Supp. 2d 1168, 1173 (N.D. Cal. 2000) (rejecting classification of domain names as service contracts because right to use domain names "exists separate and apart from [domain name registrar's] various services that make domain names operational Internet addresses [as these] services are ... mere conditions subsequent" and holding domain names intangible property).

The Ninth Circuit has recently certified questions for a California state court to answer regarding the tort of conversion of domain names. The Ninth Circuit asked:

Is an Internet domain name within the scope of property subject to the tort of conversion? (a) For the tort of conversion to apply to intangible property, is it necessary that the intangible property be merged with a document or other tangible medium? (b) If the answer to Question (a) is "yes," does the tort of conversion apply to an Internet domain name, or, more specifically, is an Internet domain name merged with a document or other tangible medium?

Kremen v. Cohen, 325 F.3d 1035, 1038 (9th Cir. 2003); see, e.g., Eric Kohm, When "Sex" Sells: Expanding the Tort of Conversion to Encompass Domain Names, 23 LOY. L.A. ENT. L. REV. 443 (2003); Mike Tonsing, "Webjacking" Case Stirs Interest in Ninth Circuit, 50 FED. LAW. 16, 18 (2003).

s8 See Kremen v. Cohen, 2000 WL 1811403, at 3 (N.D. Cal. Nov. 27, 2000) (finding domain names are form of intangible property that can be owned and transferred to others for value); Warren E. Agin, Workouts and Bankruptcy in the E-commerce Economy, 846 PLI/Comm 379, 445-450 (2003) (analyzing domain names as intangible property); see also Alexis Freeman, Internet Domain Name Security Interests: Why Debtors Can Grant Them and Lenders Can Take Them in This New Type of Hybrid Property, 10 AM. BANKR. INST. L. REV. 853 (2002). 
secured transactions. ${ }^{89}$ Domain names are often among the most valuable property of a bankrupt estate. ${ }^{90}$

\section{THE INTELLECTUAL PROPERTY BANKRUPTCY PARADIGM}

\section{A. The Exclusion of Trademarks From Intellectual Property Bankruptcy}

Current bankruptcy law distinguishes between trademarks and other types of intellectual property such as patents, trade secrets, and copyrights. ${ }^{91}$ While the law recognizes patents, trade secrets, and copyrights as intellectual property and accords them special protection, trademarks are excluded from this protected intellectual property status. $^{92}$ Specifically, a licensee of patents, trade secrets, or copyrights has a right to continue to use the intellectual property after the bankrupt licensor has rejected ${ }^{93}$ the license agreement in a bankruptcy proceeding. ${ }^{94}$ Under bankruptcy law, a bankrupt licensor can elect to

${ }^{89}$ See Xuan-Thao N. Nguyen, Commercial Law Collides with Cyberspace: The Trouble with Perfection -Insecurity Interests in the New Corporate Asset, 59 WASH. \& LEE L. REV. 37, 74-75 (2002) (proposing methods of perfecting security interest in domain names in secured transactions).

9o A. Mechele Dickerson, From Jeans to Genes: The Evolving Nature of Property of the Estate, 15 BANKR. DEV. J. 285, 304 (1998) (commenting that domain names and other intangible property are now part of bankruptcy estate); Farah Z. Usmani, Note, Information Privacy and Internet Company Insolvencies: When a Business Fails, Does Divestiture or Bankruptcy Better Protect the Consumer?, 8 FORDHAM J. CORP. \& FIN. L. 273, 276 (2003) (stating that for many e-commerce businesses that are in financial trouble, among their most valuable assets are domain names and customer lists).

9 See Patrick Law, Intellectual Property Licenses and Bankruptcy - Has the IPLBA Thawed the "Chilling Effects" of Lubrizol v. Richmond Metal Finishers, 99 COMPUTER/L.J. 261, 271 (1994) (explaining reasons for exclusion of trademarks from bankruptcy protection available for other types of intellectual property); Joseph $\mathrm{H}$. Smolinsky, The Treatment of Trademarks and Trademark Licenses in Bankruptcy, 744 PLI/Pat 225, 249 (2003) (stating that trademarks are excluded from bankruptcy protection available for other forms of intellectual property).

${ }_{92}$ See generally Stuart M. Riback, The Interface of Trademarks and Bankruptcy, 6 No. $6 \mathrm{~J}$. PROPRIETARY RTS. 2, 6 (1994) (stating that under bankruptcy law "intellectual property" includes only patents, copyrights, trade secrets, and semi-conductor chip mask works); Smolinsky, supra note 91, at 248 (noting that definition for intellectual property does not include trademarks).

${ }_{93}$ See Michael T. Andrew, Executory Contracts in Bankruptcy: Understanding "Rejection," 59 U. COLO. L. REV. 845, 919 (1988) (stating that rejection of license is treated as if licensor debtor has broken promise and will not perform its obligations).

${ }^{94}$ See Richard M. Cieri et al., Protecting Technology and Intellectual Property Rights When a Debtor Infringes on Those Rights, 8 AM. BANKR. INST. L. REV. 349, 355-56 (2000) (explaining that licensee has two options: it may decide to treat license as terminated and assert claim for breach of contract damages or it may choose to retain its licensed rights in intellectual 
reject, that is, to breach, the license agreement by effectively severing the license grant. ${ }^{95}$ The bankruptcy law's special protection shields patent, trade secret, and copyright licensees from the impact of such rejection. The licensee of a trademark, however, has no such special protection; it cannot use the trademark after the bankruptcy licensor rejects the trademark license agreement. ${ }^{96}$

Thus, when a licensor in bankruptcy rejects a trademark license, the licensee is forced to discontinue all use of the trademark in connection with the sale of its goods or services and in the daily operation of its business. $^{97} \quad$ All trademark use must come to an abrupt end. ${ }^{98}$ The trademark licensee's only right is an unsecured claim for money damages against the debtor or the trustee of the bankrupt licensor's estate.

At the opposite end of the spectrum, a licensee of patents, copyrights, or trade secrets can continue to operate its business without interruption when the licensor rejects the license in bankruptcy. ${ }^{100}$ The licensee may continue to use the license rights granted under the patent, copyright, or trade secret license to make, use, or sell its products or services, incorporating the protected inventions, copyrights, or know-how. ${ }^{101}$

property and continue to pay royalty fees to licensor debtor).

${ }_{95}$ See Brent Capehart, How Bankruptcy Can Affect a Client's Intellectual Property Rights, 38 ARK. L. REV. 20, 22 (2003) (stating that rejection of license agreement means agreement is "breached (but generally not automatically terminated) and the non-debtor party has a prepetition claim for that breach of contract").

* See generally Law, supra note 91, at 271.

97 See David Jenkins, Comment, Licenses, Trademarks, and Bankruptcy, Oh My!: Trademark Licensing and the Perils of Licensor Bankruptcy, 25 J. MARSHALL L. REV. 143, 157-58 (1991) (stating that trademark licensee loses its right to use trademark in its business in post-rejection).

${ }^{98}$ See Riback, supra note 92, at 66 (stating that rejection of trademark license can potentially destroy licensee's business because it is deemed to be pre-petition breach by licensor debtor); see also In re Blackstone Potato Chip Co., Inc., 109 B.R. 557, 562 (Bankr. D. R.I. 1990) (stating that upon rejection, licensee was left with no rights to use trademark).

99 See Andrew, supra note 93, at 919 (stating that upon licensor debtor's rejection, nondebtor licensee has basis for breach of contract claim for damages under bankruptcy law); see also In re Centura Software Corp., 281 B.R. 660, 673 (Bankr. N.D. Cal. 2002) (holding that in post-rejection, trademark licensee is only entitled to file unsecured pre-petition claim for damages resulting from inability to use licensed trademarks).

${ }^{100}$ See generally Scott A. Steinberg \& Michael A. Gerber, Software Licensing: Protecting Intellectual Property in Bankruptcy, 6 BANKR. L. \& PRAC. 535, 544-45 (1997) (stating that software licensees can retain their right to use software after licensor debtor rejected license); Robert T. Caravan, Comment, Recent Trends in Bankruptcy Law, 21 SETON HALL L. REV. 800, 803 (1991) (stating that licensees of technology are permitted to continue their use of technology for term of license, notwithstanding rejection).

10 See Tony K. Ho \& Sujun Kim, Intellectual Property Issues in an Insolvency Context, 1307 PLI/Corp 173, 185-86 (2002) (stating that licensee has unimpeded use of licensed 
This discrepancy in the treatment of trademarks on the one hand, and patents, copyrights, and trade secrets on the other, seems to indicate that trademarks are not as esteemed as patents, copyrights, and trade secrets. ${ }^{102}$ Such treatment suggests that the use of trademarks in commerce is not as important as the use of the other three types of intellectual property. ${ }^{103}$ This discrepancy also suggests that a disruption in trademark use is not as harmful as a disruption in the use of patents, trade secrets, or copyrights. ${ }^{104}$ The decision to systematically exclude trademarks from the special treatment reserved only for the other three suggests that it was formed in haste, ${ }^{105}$ under the banner of societal benefits. ${ }^{106}$ The perplexing and polemic decision is embodied in the Intellectual Property Licenses in Bankruptcy Act.

intellectual property after licensor debtor rejects license agreement). Further, the licensor debtor is obligated to turn over any intellectual property or embodiment thereof to which the licensee is entitled under the license or any supplementary agreement. The licensor must also refrain from interfering with the licensee's rights under the license or any supplementary agreement if the licensee makes this request in writing. Id.

102 See Cieri, supra note 94, at 355-56 (stating that bankruptcy law provides protection to licensees of patents, copyrights, and trade secrets because law wants to promote development and licensing of these intellectual property rights since these rights are necessary for licensees to operate substantial parts of their businesses).

${ }^{103}$ In deciding to exclude trademarks from the protection, Congress focused on the impact of the licensing of technology such as patents, copyrights, and trade secrets. This suggests that the license of trademarks in commerce is not as important and thus not worthy of the same protection. See Noreen Wiggins, Note, The Intellectual Property Bankruptcy Protection Act: The Legislative Response to Lubrizol Enterprises, Inc. v. Richmond Metal Finishers, Inc., 16 RUTGERS COMPUTER \& TECH. L.J. 603, 620 (1990) (explaining legislative purposes of bankruptcy protection statute for certain forms of intellectual property).

${ }_{104}$ As commentators have noted, protection is available for patents, copyrights, and trade secrets to prevent the destruction of the licensee's business. The explicit exclusion of trademarks from the same protection strongly suggests that such exclusion does not cause the same level of destruction to the licensee's business. See Randy Michelson, Bankruptcy \& Licensing, $704 \mathrm{PLI} /$ Pat 247, 261 (2002) (stating that protection available for licensees of patents, copyrights, and trade secrets is to prevent destruction of businesses dependent upon bankruptcy licensors' intellectual property for success of its business operations).

105 See infra Part V.

106 Patents, copyrights, and trade secrets are protected because courts recognize that licensing these rights both provides owners with monetary gain, and society with benefits from technological development and innovation. Thus, allowing the licensees to continue to use the licenses in post-rejection encourages the development of technology and innovation. See Law, supra note 91, at 264 (explaining how protection afforded licensees of patents, copyrights, and trade secrets will encourage investment in intellectual property and reverse any chilling effect on development and licensing of intellectual property); Wiggins, supra 103, at 620 (explaining how licensing arrangements benefit both industry and society; rejection of arrangements would have chilling effect on technological development). 


\section{B. The Intellectual Property Licenses in Bankruptcy Act}

Congress passed the Intellectual Property Licenses in Bankruptcy Act ("the Act") in October $1988^{107}$ in response to the Fourth Circuit Court of Appeals' decision in Lubrizol Enterprises, Inc. v. Richmond Metal Finishers, Inc. ${ }^{108}$ The Lubrizol court authorized the debtor licensor's unilateral rejection of a license agreement concerning metal coating process technology. ${ }^{109}$ Under then current bankruptcy law, the licensee could treat the rejection as a breach and seek monetary damages, but could not retain its license rights in the technology by demanding specific performance. ${ }^{110}$ Essentially, rejection extinguished the licensee's right to use the technology. ${ }^{111}$ The denial of the right to use the technology license threatened the licensee's business. ${ }^{112}$ Lubrizol's harsh outcome led to passage of the IPLBA. ${ }^{13}$

The IPLBA is designed to promote the development and licensing of intellectual property by preventing the rejection of a license from unilaterally terminating the rights of an intellectual property licensee to use the licensed property. ${ }^{14}$ In passing the IPLBA, Congress also sought to encourage investment in intellectual property and to protect the rights of technology licensees who contribute significantly to the financing, research, development, manufacturing, and marketing of intellectual

107 Intellectual Property Licenses in Bankruptcy Act, Pub. L. No. 100-506, 102 Stat. 2538 (1988) (codified at 11 U.S.C. $\$ 365(n)(2000)$ ).

${ }_{108} 756$ F.2d 1043 (4th Cir. 1985), cert. denied, 475 U.S. 1057 (1986). See generally Wiggins, supra note 103, at 603 (discussing Lubrizol and Congress' response).

${ }_{109}$ Lubrizol, 756 F.2d at 1048 (recognizing harsh result of its holding and stating that Congress had afforded special treatment for certain types of executory contracts under Bankruptcy Code, but that Code did not contain any comparable treatment of technology licenses).

110 See id. (stating that applicable bankruptcy provision only allowed limited monetary damages, but not specific performance for non-bankrupt party in post-rejection).

${ }^{111}$ Id. (stating that licensee could not continue to use technology because such use would undercut core purpose of rejection under bankruptcy law).

112 The Lubrizol court acknowledged that the consequences to the licensee were harsh and might have a chilling effect upon the willingness of licensees to contract at all with licensors in financial difficulties. Id. The court stated, "Congress has plainly provided for the rejection of executory contracts, notwithstanding the obvious adverse consequences for contracting parties thereby made inevitable." Id.

113 See Richard M. Cieri \& Michelle M. Morgan, Licensing Intellectual Property and Technology From the Financially-Troubled or Startup Company: Prebankruptcy Strategies to Minimize the Risk in a Licensee's Intellectual Property and Technology Investment, 55 BUS. LAW. $1649,1652(2000)$ (stating that statute was enacted to correct detrimental impact that Lubrizol and progeny have had on technology industry).

114 See H.R. REP. NO. 100-1012, at 6 (1988) (explaining purpose of legislation); S. REP. No. 100-505, at 1 (1988) (stating purpose of bill). 
property. $^{115}$

The IPLBA provides special protection to intellectual property licensees when the debtor licensor is in bankruptcy. The IPLBA permits a licensee to retain its right under a license even when the debtor licensors files a bankruptcy petition and decides to reject the license. ${ }^{116}$ The IPLBA defines intellectual property as: (a) trade secret, (b) invention, process, design, or plant protected under Title 35, (c) patent application, (d) plant variety, (e) work of authorship protected under Title 17, or $(f)$ mask work protected under Chapter 9 of Title $17 .{ }^{117}$ The definition of intellectual property deliberately excludes trademarks. ${ }^{118}$

The immediate concerns that gave rise to the IPLBA are perhaps responsible for the omission of trademarks from the Act's protection. ${ }^{11}$

115 S. REP. NO. 100-505, at 3-4 (1988) (explaining role of licensing and how then-current bankruptcy law harmed licensors and licensees); see also Law, supra note 91, at 264 (discussing how bankruptcy protection statute for intellectual property would provide licensees with incentives to invest in development, manufacturing, and marketing of intellectual property).

116 The IPLBA has been codified as 11 U.S.C. $\$ 365(n)(2000)$.

117 The definition of intellectual property in the IPLBA has been codified as 11 U.S.C. $\S 101(35 \mathrm{~A})(2003)$.

${ }^{118}$ The Senate Report accompanying S. 1626 states that "the bill does not address the rejection of executory trademark, trade name or service mark licenses." S. REP. NO. 100505, at 5 (1988). See generally WILLIAM L. NORTON, JR., BANKRUPTCY LAW \& PRACTICE 39:57 (2002) (stating that Bankruptcy Code defines intellectual property broadly to protect many types of rights other than trademarks); Warren E. Agin, Drafting the Intellectual Property License: Bankruptcy Considerations, 9 J. BANKR. L. \& PRAC. 591 (2000) (stating that section 365(n) of Bankruptcy Code does not provide protections for licensees of trademarks); Mary William, Survey: The Treatment of Intellectual Property Interests in Bankruptcy, 4 J. BANKR. L. \& PRAC. 391, 397 (1995) (explaining definition of intellectual property includes virtually all types of intellectual property protected by federal, state, statutory, and common law; though one must interpret definition liberally, trademarks, trade names, and publicity rights are not included in definition).

119 Legislative history of the IPLBA indicates that Congress became concerned about the treatment of intellectual property licenses under bankruptcy law largely due to the Lubrizol case and the awareness that the "high technology industry ... is ... so vital to our nation's economy." Intellectual Property Contracts in Bankruptcy: Hearing on H.R. 4657 Before the Subcomm. on Monopolies and Commercial Law, 100th Cong. 10 (1988) [hereinafter Hearings] (statement of Rep. Peter W. Rodino, Jr. Chairman, Subcomm. on Monopolies and Commercial Law).

Likewise, Representative Don Edwards, who introduced H.R. 4657, raised similar concerns about technology licenses:

I introduced this bill last month because of my concerns about the need for continued licensing of intellectual property rights and about the chill on the free flow of intellectual property created under the bankruptcy code by recent court decisions.

As we all know from the new products and services that crop up in our daily 
The Lubrizol decision, which prompted Congress' passage of the IPLBA, focused on technology. It is not surprising, then, that the Act protected the licensees of intellectual property defined only as patents, trade secrets, and copyrights. These forms of intellectual property may have simply overshadowed trademarks during the passage of IPLBA. Indeed, the House Report indicates that Congress was preoccupied with "the need to foster the development of new technology and new ideas, and to maintain the United States' world leadership in the area of new technology development." ${ }^{120}$ Congress recognized that in the technology licensing context, licensees "use the licensed technology as the basis for an entire business," and if the licensor rejected the license agreement and withdrew the technology, the licensees would be left without the technology and possibly would be unable to obtain adequate substitute technology. ${ }^{121}$ Such immediate concerns with technology resulted in legislation to protect the licensees of technology and ideas, even when the bankrupt licensor has expressly decided not to honor the license agreement. $^{122}$ In summary, the IPLBA was a reaction to the Lubrizol

lives, we are in the midst of a technological revolution. Over the past 40 years, the American economy has thrived on the development of new ideas and inventions. Frequently, this new technology makes its way into the marketplace through intellectual property licensing agreements, with the business, university, or individual entrepreneur who developed that intellectual property granting a license to someone else to use or market it. Entire businesses may be built upon the intellectual property licensed from other parties.

Recent decisions under the bankruptcy laws, however, put this system of licensing into jeopardy by threatening a licensee's continued use of intellectual property after the licensor files bankruptcy.

Of particular concern is the decision in Lubrizol Enterprise, Inc. v. Richmond Metal Finishers, Inc.

Id. (statement of Rep. Don Edwards).

H.R. 4657 was later amended and Representative Edwards introduced a clean bill, H.R. 5348, which the House subsequently passed on October 4, 1988. See H.R. REP. NO. 100-1012, at 1-2 (1988) (stating procedural background of H.R. 5348).

${ }_{120}$ H.R. REP. NO. 100-1012, at 4 (explaining background of bill).

${ }^{121}$ Id. at 6 (illustrating example of computer manufacturer licensee that faced serious consequences of licensor's rejection).

122 See S. REP. NO. 100-505, at 3 (1988) ("Licensing of technology, which the bill is intended to protect and facilitate, plays a substantial role in the process of technological development and innovation."); see also Madlyn Gleich Primoff \& Erica G. Weinberger, Ecommerce and Dot-com Bankruptcies: Assumption, Assignment and Rejection of Executory Contracts, Including Intellectual Property Agreements, and Related Issues Under Section 365(c), 365(e) and 365(n) of the Bankruptcy Code, 8 AM. BANKR. INST. L. REV. 307, 342-43 (2000) (stating that while IPLBA permits licensee to retain the intellectual property license that 
decision. It merely responded to the then perceived chilling effects Lubrizol would have had on the licensee's right to use the technology license. The Act ignored the licensee's right to use a trademark license.

Congress expressed only a passing concern for the exclusion of trademarks from the IPLBA's protection. ${ }^{123}$ Legislative history indicates that Congress recognized the importance of trademark licenses. ${ }^{124}$ Congress admitted that the rejection of trademark licenses is "of concern" because of the harsh interpretation of section 365 by the Lubrizol court. ${ }^{125}$ Congress, however, avoided addressing this concern, stating, in the words of the legislative report, that "since these matters could not be addressed without more extensive study, it was determined to postpone Congressional action in this area., ${ }^{126}$

Not only did Congress postpone its decision to address the concerns relating to the rejection of trademarks by debtor-licensors, it conveniently passed the ball to the bankruptcy courts. ${ }^{127}$ The legislative history indicates that Congress wanted the bankruptcy courts to develop "equitable treatment of this situation." ${ }^{\text {"128 }}$ Because congressional concerns regarding the exclusion of trademarks from bankruptcy protection is imbedded in the legislative history, while the plain language of the IPLBA indicates the explicit exclusion of trademarks, a bankruptcy court considering the rejection of a trademark license is in a difficult situation. It may decide that it is bound by the plain language of the IPLBA and summarily authorize the rejection of the trademark license, thereby extinguishing the licensee's right to use the trademark. ${ }^{129}$ Alternately, it may give weight to Congress' concerns regarding the exclusion of trademarks, and conclude that permitting the licensee to retain the use of

existed pre-petition, it does not permit licensee to post-rejection enforcement of licensor debtor's ongoing obligations to provide service, maintenance, future upgrades, and improvements of intellectual property per original license agreement).

123 See S. REP. NO. 100-505, at 5.

124 Id.

${ }^{125}$ Id. (stating that rejection of trademark, trade name, or service mark license by debtor licensors "is of concern because of the interpretation of section 365 by the Lubrizol court and others").

${ }^{126}$ Id. (explaining that concerns relating to rejection of trademark licenses are "beyond the scope of this legislation").

${ }_{127}$ Id.

${ }^{128}$ Id.

129 See generally In re Centura Software Corp., 281 B.R. 514 (Bankr. S.D. Fla. 1993) (applying plain meaning of section $365(\mathrm{n})$ and declining to conduct judicial inquiry into legislative history); In re Blackstone Potato Chip Co., Inc., 109 B.R. 557 (Bankr. D.R.I. 1990) (ignoring section 365(n) and authorizing rejection of trademark license agreement). 
the trademark falls within the court's equitable powers. ${ }^{130}$ This latter approach would rest on the belief that even though the plain language of the IPLBA excludes the protection of trademark licenses, the bankruptcy court can allow the licensees to continue to use the trademark license if the court deems the use to be equitable. ${ }^{131}$

Yet another bankruptcy court, however, may decide that weighing the equities depends on the licensee's timeliness in raising its concern to the court. ${ }^{132}$ If the licensee raises its concern pre-rejection, the court may be more inclined to consider the matter, particularly if the trademark license is part of a bundle of rights to use with other intellectual property protected under the IPLBA. ${ }^{133}$ If the licensee raises its concern postrejection, the court may rule that it has no choice but to apply the strict language of the IPLBA, and exclude the trademark from protection because the trademark license itself has already been rejected. ${ }^{134}$ All of this indicates that all concerned parties - the debtor, the licensee, and the unsecured creditors - are on uncertain ground in bankruptcy cases involving debtor trademark licensors.

\section{Intellectual Property Paradigm - Patents, Trade Secrets, and Copyrights Only}

The plain language of the IPLBA creates an intellectual property paradigm in which only patents, trade secrets, and copyrights are protected. ${ }^{135}$ Are there some qualities unique to patents, copyrights, and

130 See generally In re Matusalem \& Matusa of Fla., Inc., 158 B.R. 514, 516 (Bankr. N.D. Fla. 1993) (stating that legislative history of IPLBA "is helpful in more fully understanding legislation. Such a look in this case does help decide the issue. Thus the ball is back in the Court's court. The court is impressed by the stated purpose of the Bill, the similarity of provisions of the Code as to the treatment of lessors and lessees, and in this situation, the plain language of 365(n).").

131 Id.

${ }^{132}$ See In re Centura Software, 281 B.R. at 670 (discussing importance of timing when trademark licensee raises their concern to court and dictates what court can consider in prerejection and post-rejection motion brought by trademark licensee).

133 See id.

134 See id. (stating that court is bound by plain language of IPLBA and could not consider equity argument raised by trademark licensee in post-rejection motion).

135 Congress believed that patents, copyrights, and trade secrets were the types of intellectual property crucial to the advancement of technology, and legislation to protect the licenses of these rights was immediate. See generally H.R. REP NO. 100-1012, at 4 (1988) ("[T]he Committee is persuaded that the overall interests of the economy are best served by creating another exception to section 365 now."); S. REP. NO. 100-505, at 9 (1988) ("This bill is intended to restore confidence in the system of intellectual property licensing, and courts interpreting it should be sensitive to the reasonable practices that have and will evolve among parties seeking to add to the technological and creative wealth of America."). 
trade secrets that merit the special protection? Do certain forms of intellectual property deserve more protection because they are grounded in the Constitution? Do the different characteristics of the various forms of intellectual property justify the intellectual property paradigm?

Both copyrights and patents have a constitutional basis. The United States Constitution expressly provides that for a limited time writers and inventors receive protection for their writings and inventions, respectively. ${ }^{136}$ The Constitution, however, does not contain any clauses specifically addressing trade secrets. ${ }^{137}$

Copyright law protects a broad range of original works of authorship, including literary, musical, and architectural works, as well as computer software codes. ${ }^{138}$ A copyright provides the author ${ }^{139}$ a bundle of rights such as the right to reproduce the work, to make derivative works, to distribute copies, to display the work, and to perform the work. ${ }^{140}$ The term of a copyright is the life of the author plus seventy years. ${ }^{141}$ If the work is a work for hire, ${ }^{142}$ the term of such copyright is ninety-five years

${ }^{136}$ U.S. CONST. art. I, $\S 8$ ("To promote the Progress of Science and useful Arts, by securing for limited Times to Authors and Inventors the exclusive Right to their respective Writings and Discoveries.").

${ }_{137}$ See Lars Smith, Trade Secrets in Commercial Transactions and Bankruptcy, 40 IDEA 549, 551 (2000) (discussing trade secret protection under uniform model statute).

${ }^{138}$ Copyright law extends protections to works of authorship in eight broad categories such as: (1) literary works; (2) musical works, including any accompanying words; (3) dramatic works, including any accompanying music; (4) pantomimes and choreographic works; (5) pictorial, graphic, and sculptural works; (6) motion pictures and other audiovisual works; (7) sound recordings; and (8) architectural works. See 17 U.S.C. § 102 (2000) (listing works of authorship for copyright protection). Copyright protection is also available for software. See generally Data Gen. Corp. v. Grumman Sys. Support Corp., 825 F. Supp. 340 (D. Mass. 1993) (considering copyright infringement of software); Stephen M. McJohn, The Paradoxes of Free Software, 9 GEO. MASON L. REv. 25, 36 (2000) (discussing aspects of computer software entitled to copyright protection).

139 Under copyright law, authors can be individuals or corporations. See Jane Ginsburg, The Concept of Authorship in Comparative Copyright, 52 DEPAUL L. REV. 1063, 1069 (2003) (examining legal concept of authorship under various copyright laws).

${ }_{140}$ See generally Todd Hagins, Grabbing Peter Gabriel to Pay Paul's Dinner: Plunder, the Free Market, and the Fairness in Music Licensing Act, 7 TEX. REV. L. \& POL. 385, 389-90 (2003) (discussing statutory rights held by copyright owners); Brian Mencher, Digital Transmissions: To Boldly Go Where No First Sale Doctrine Has Gone Before, 10 UCLA ENT. L. REV. 47, 52 (2002) (listing rights included in copyright's bundle of rights under federal copyright law).

${ }_{141}$ See Joseph P. Liu, Copyright and Time: A Proposal, $101 \mathrm{MiCH}$. L. REV. 409, 413-17 (2002) (detailing evolving change in copyright term from Statute of Anne to Copyright Term Extension Act).

142 A "work made for hire" is:

(1) a work prepared by an employee within the scope of his or her employment; or (2) a work specially ordered or commissioned for use as a contribution to a 
from registration or 120 years from creation, whichever is longer. ${ }^{143}$

A patent is a negative right because under the law a patent owner has only the right to exclude others from making, using, selling, or offering for sale, or importing the patented invention. ${ }^{144}$ Patent protection lasts for twenty years from the date the patent application is filed with the Patent Office. ${ }^{145}$ It is available to an invention that is novel ${ }^{146}$ and is not obvious ${ }^{147}$ to a person with ordinary skill in the field of invention. ${ }^{148}$ The subject matter eligible for patent protection is broad, ranging from mechanical, to biotech, and even to methods of doing business, otherwise known as Internet patents. ${ }^{149}$

collective work, as a part of a motion picture or other audiovisual work, as a translation, as a supplementary work, as a compilation, as an instructional text, as a test, as answer material for a test, or as an atlas, if the parties expressly agree in a written instrument signed by them that the work shall be considered a work made for hire.

17 U.S.C. $\S 101$ (2000). See also Kwall, supra note 24, at 1000 (analyzing "work made for hire" doctrine and how courts have interpreted it).

${ }^{143}$ See Irene Segal Ayers, The Future of Global Copyright Protection: Has Copyright Law Gone too Far?, 62 U. PITT. L. REV. 49, 73 (2000) (noting that Congress, for fourth time in history of copyright law, extended copyright term and that under current law work-forhire has term of 95 years from registration); see also Jon M. Garon, Media $\&$ Monopoly in the Information Age: Slowing the Convergence at the Marketplace of Ideas, 17 CARDOZO ARTS \& ENT. L.J. 491, 523 (1999) (stating that corporation authors of copyrights benefit most from Copyright Term Extension Act under which such authors receive 20 more years to term of 95 years).

${ }_{144}$ See generally, Caroline Frances Barry, Chemical Claims Drafting After Lubrizol, $20 \mathrm{~J}$. MARSHALL J. COMPUTER \& INFO. L. 207, 227-28 (2002) (stating that under U.S. patent system, patent grant is negative right); Janice Mueller, No "Dilettante Affair:" Rethinking the Experimental Use Exception to Patent Infringement for Biomedical Research Tools, 76 WASH. L. REV. 1, 50 (2001) (explaining that patentee has negative right to exclude others from using patented invention, not affirmative right to use invention).

145 See generally Donna M. Gitter, International Conflict Over Protecting Human DNA Sequences in the U.S. E the European Union: An Argument for Compulsory Licensing \& Fair Use Exemption, 76 N.Y.U. L. REV. 1623, 1637 (2001) (discussing term of patent grant under U.S. patent law).

146 See, e.g., Linda J. Demaine \& Aaron Xavier Fellmeth, Reinventing the Double Helix: A Novel and Nonobvious Reconceptualization of the Biotechnology Patent, 55 STAN. L. REV. 303, 384-88 (2002) (examining novelty requirement).

147 See, e.g., Margo A. Bagley, Patently Unconstitutional: The Geographical Limitation on Prior Art in a Small World, 87 MINN. L. REv. 679, 694-95 (2003) (analyzing non-obviousness requirement).

${ }^{148}$ In addition to the novelty and non-obvious requirements, there are other requirements such as patentable subject matter, utility, and enablement. See Arti K. Rai, Engaging Facts and Policy: A Multi-Institutional Approach to Patent, 103 COLUM. L. REv. 1035, 1045 (2003) (discussing patentability requirements).

149 See generally Vincent Chiappetta, Defining the Proper Scope of Internet Patents: If We Don't Know Where We Want to Go, We're Unlikely to Get There, 7 MiCH. TELECOMM. \& TECH. L. REV. 289, 296-300 (discussing expansion of scope of patentable subject matter in recent 
Protection for trade secrets began in the common law and was later codified in the Uniform Trade Secrets Act. ${ }^{150}$ This Act gave the trade secret owner a cause of action against misappropriation, if the information or know-how qualifies as a trade secret and the owner has safeguarded its secrecy. ${ }^{151}$ A trade secret enjoys protection against misappropriation as long as the owner safeguards it. ${ }^{152}$ In a trade secret license arrangement, the licensor requires the licensee to execute a confidentiality agreement and to follow certain measures to safeguard secrecy. ${ }^{153}$

years); Joel M. Freed \& Thomas C. Reynold, The New Patent Landscape, in 18 No. 12 COMPUTER \& INTERNET LAW. 1-3 (2001) (reviewing case law on subject matter of patent protection).

${ }^{150}$ Historically, trade secrets have enjoyed protection under common law. See generally, Matthew R. Millikin, Note, www.misappropriation.com: Protecting Trade Secrets After Mass Dissemination on the Internet, 78 WASH. U. L.Q. 931, 937 (2000) (providing brief history of trade secret protection in United States). In 1979, the National Conference of Commissioners on Uniform State Laws began to promulgate a model state trade secrets statute, the Uniform Trade Secret Act. See UNIF. TRADE SECRET ACT, 14 U.L.A. 438 (1990).

151 Misappropriation includes (i) acquisition of a trade secret of another by a person who knows or has reason to know that the trade secret was acquired by improper means; or (ii) disclosure or use of a trade secret of another without express or implied consent by a person who

(A) used improper means to acquire knowledge of the trade secret; or

(B) at the time of disclosure or use, knew or had reason to know that his knowledge of the trade secret was

I. derived from or through a person who had utilized improper means to acquire it; II. acquired under circumstances giving rise to a duty to maintain its secrecy or limit its use; or

III. derived from or through a person who owed a duty to the person seeking relief to maintain its secrecy or limit its use; or

(C) before a material change of his or her position, knew or had reason to know that it was a trade secret and that knowledge of it had been acquired by accident or mistake.

UNIF. TRADE SECRET ACT § 1(2), 14 U.L.A. 438 (1990).

152 The secrecy requirement is integral to the protection of a trade secret, as seen in the definition of trade secret. See id. (stating that trade secret is "information, including a formula, pattern, compilation, program, device, method, technique, or process that: (i) derives independent economic value, actual or potential, from not being generally known to, and not being readily ascertainable by proper means by other persons who can obtain economic value from its disclosure or use, and (ii) is the subject of efforts that are reasonable under the circumstances to maintain its secrecy.").

${ }_{153}$ Such practice is part of the trade secret owner's efforts that are reasonable under the circumstances to maintain its secrecy. See generally M. Scott McBride, Bioinformatics and Intellectual Property Protection, 17 BERKELEY. TECH. L.J. 1331, 1353 (2002) (stating that confidentiality agreement is often used to prevent contracting party from disclosing trade secrets). 
Peculiarly, though they are excluded from the bankruptcy law's definition of intellectual property, trademarks share many characteristics possessed by copyrights, patents, and trade secrets. ${ }^{1.4}$ Similar to the negative right in patents, the owner of a trademark has the right to exclude others from using a confusingly similar trademark. ${ }^{155}$ In addition, similar to trade secret protection, trademark protection is rooted in the common law. ${ }^{156}$ Like trade secrets, trademark protection is not expressly included in the Constitution's clause for patent and copyright protection. ${ }^{157}$ Interestingly, as in trade secret protection, trademark protection is of indeterminate duration. ${ }^{158}$ Provided that the trademark owner maintains its goodwill and reputation among consumers through use of the trademark in commerce, the trademark is protected as long as it is used. ${ }^{159}$ Similar to copyright, patent, and trade

${ }_{154}$ Economists and legal scholars often treat patents, trade secrets, copyrights, and trademarks as discrete and insular. Such treatment places the academic theory of intellectual property at odds with the use of intellectual property in the real world. Parchomovsky \& Siegelman, supra note 10, at 1457.

155 See id., at 1459 (discussing trademark owner's exclusionary right). See generally Adam Mossoff, What is Property? Putting the Pieces Back Together, 45 ARIZ. L. REV. 371, 423 (2003) ("In the context of trademark law, the owners of trademarks were originally accorded legal protection because the creation of trademarks represented the essence of property rights, i.e., the marks were things used for value-creating purposes, which served as the basis for an individual's entitlements to them and the exclusion of others.").

156 See, e.g., The Trade-Mark Cases, 100 U.S. 82, 94 (1879) ("The trade-mark recognized by the common law is generally the growth of a considerable period of use, rather than a sudden invention.").

157 See id. at 96 (holding that federal trademark statute in 1870 enacted under patent and copyright clause of Con'stitution was unconstitutional).

${ }_{158}$ See Jon D. Grossman \& Eric Oliver, Licensing Business Method Patents, 740 PLI/Pat 257, 266 (2003) ("The term for a trade secret is potentially indefinite."). Although the protection for trademarks and trade secrets is rooted in common law, the law much more readily treats trade secrets as "property." See Ruckelshaus v. Monsanto Co., 467 U.S. 986, 1002-04 (1984) (ruling that trade secret is property because it has "many of the characteristics of more tangible forms of property. A trade secret is assignable. A trade secret can form the res of a trust, and it passes to a trustee in bankruptcy."). Trademark law, on the other hand, protects both the consumer and the trademark owner who substantially invested in the trademark and has the right to "reap the financial, reputationrelated rewards" of the trademark. See Qualitex Co. v. Jacobson Prods. Co., 514 U.S. 159, 163-64 (1995).

159 See Trade-Mark Cases, 100 U.S. at 94 (recognizing trademark right is based on use); Davis J. Kera \& Theodore H. Davis, Jr., The Fifty-Fifth Year of Administration of the Lanham Trademark Act of 1946, 93 TRADEMARK REP. 197, 404 (2003) (explaining that statutory abandonment of trademark occurs when trademark owner stops using trademark for period of time); see also Parchomovsky \& Siegelman, supra note 10 at 1459 (stating that trademark protection is infinite in duration because it lasts as long as companies establish and maintain goodwill and preserve their reputation among consumers). If the non-use of the trademark lasts three years, there is a presumption that the trademark owner has abandoned its trademark. Kera \& Davis, supra, at 404. 
secret protections, trademark protection allows the trademark owner to obtain an injunction against unauthorized use of the trademark. ${ }^{160}$ Like copyrights, ${ }^{161}$ patents, and trade secrets, ${ }^{162}$ trademarks can be licensed and assigned. ${ }^{163}$ A trademark owner can sell its trademark to another person or business entity along with the goodwill embodied in the trademark. ${ }^{164}$ The owner can use the trademark as collateral in secured credit financing transactions. ${ }^{165}$ The owner can license the trademarks to a third party, on either an exclusive ${ }^{166}$ or non-exclusive basis. ${ }^{167}$

160 See Int'l Order of Job's Daughters v. Lindelburg \& Co., 633 F.2d 912, 919 (9th Cir. 1980), cert. denied, 452 U.S. 941 (1981) ("[T]he 'property right' or protection accorded a trademark owner can only be understood in the context of trademark law and its purposes. A trademark owner has a property right only insofar as is necessary to prevent consumer confusion as to who produced the goods and to facilitate differentiation of the trademark owner's goods.").

${ }_{161}$ See Aaron Xavier Fellmeth, Control Without Interest: State Law of Assignment, Federal Preemption, and the Intellectual Property License, 6 VA. J.L. \& TECH. 8, 70 (2001) ("Intellectual 'property' in the form of patents and copyrights is intangible property granted by federal statute, but the bundle of rights to the property can be owned like a chose in possession, which can be assigned or exclusively conferred by license. On the other hand, a nonexclusive right is merely an executory right not to be sued."); Mark A. Lemley, Beyond Preemption: The Law and Policy of Intellectual Property Licensing, 87 CAL. L. REV. 111, 144 (1999) (stating that copyright owner may license "less than her entire bundle of rights to a licensee under terms consistent with the copyright laws").

162 See Grossman \& Oliver, supra note 158, at 266-67 (noting that due to indefinable term of trade secrets, "a patent license combined with trade secrets could conceivably lengthen the term of the license beyond the lifetime of the patent"); cf. Pitney Bowes, Inc. v. Mestre, 701 F.2d 1365 (11th Cir. 1983) (ruling that package royalty payments for license of both patent and trade secrets must fail when patent expires).

${ }^{163}$ See Beech-Nut Packing Co. v. P. Lorillard Co., 273 U.S. 629, 632 (1927) (observing that "the mark is property, protected and alienable, although as with other property, its outline is shown only by the law of torts, of which the right is a prophetic summary."). To avoid "naked license" of a trademark, a trademark owner must include a quality control provision in the license agreement. See supra Part I(B); see also Sharon R. Barner, Litigation Perspective on Licensing, 672 PLI/Pat 647, 660-61 (analyzing "naked license" and discussing trademark policy behind "naked license" rule).

${ }_{164}$ The Lanham Act provides that the trademark owners can assign trademarks along with the attached goodwill. 15 U.S.C. $§ 1060$ (2000). See Mathias Strasser, The Rational Basis of Trademark Protection Revisited: Putting the Dilution Doctrine into Context, 10 FORDHAM INTELL. PROP. MEDIA \& ENT. L.J. 375, 418 (2000) (stating that under anti-assignment in gross rule, trademark owner cannot assign its trademarks to third party without attached goodwill).

${ }_{165}$ See, e.g., In re Am.'s Hobby Ctr., 223 B.R. 275 (Bankr. S.D.N.Y. 1998) (trademarks as collateral in secured transaction); In re Roman Cleanser, 43 B.R. 940 (Bankr. E.D. Mich. 1984) (same); In re TR-3 Indus., Inc., 41 B.R. 128 (Bankr. C.D. Cal. 1984) (same).

166 Under trademark law, an exclusive license of a trademark does not amount to a transfer of ownership, whereas under copyright law, an exclusive license of any of the exclusive rights under copyright is a transfer of ownership of that right. 17 U.S.C. § 201(d) (1978).

${ }^{167}$ See Mary M. Squyres, Global Licensing: A License to Use, 740 PLI/Pat 485, 489 (2003) 
Moreover, as in patent, copyright, or trade secret licensing schemes, ${ }^{168}$ a trademark owner may also license its trademarks to others who have the resources to use or market the intellectual property more effectively. ${ }^{169}$ A trademark owner may license the trademark to a company that has manufacturing capability ${ }^{170}$ or resources for marketing. ${ }^{171}$ Commentators have noted that a trademark owner sometimes finds that it is more advantageous to license its trademark than to use the trademark itself. ${ }^{172}$

Given these similarities, ${ }^{173}$ it is unclear why the Intellectual Property Bankruptcy Paradigm excludes trademarks but includes copyrights, patents, and trade secrets. ${ }^{174}$ Perhaps the Paradigm rests on the belief that unlike the other three, trademark licenses require the licensor to

(acknowledging common practice of licensing by trademark owners). The licensing practice offers the trademark owner more benefits than using the trademark itself. Id. "The licensor can sell goods/services without advertising and simultaneously guarantee the consumer a definite quality standard. Without the license, the licensee (user) would be an infringer. The license establishes a continuous relationship between two parties." Id.

${ }_{168}$ Congress recognized licensees' important role in technology licensing arrangements, noting that the process of technological development and innovation "begins with an inventive concept and must proceed through an expensive and risky series of steps including research, development, manufacturing, and marketing. At each step, both money and additional refinement of the idea are required. Often the financing and additional refinements are only available through the participation of persons other than the original innovator." S. REP. NO. 100-505, at 3 (1988).

169 See Squyres, supra note 167, at 489-90 (explaining reasons for trademark licensing), citing LADAS, supra note 46 , at 1127.

170 See Squyres, supra note 167 , at 490 (stating that licensee's manufacturing capability is reason for licensing).

${ }_{171} I d$. (noting that licensor does not have to pay for marketing expenses while goods or services are offered for sale under licensor's trademarks).

17 Id. (explaining advantages gained by trademark owner if it chose to license its trademarks).

173 As discussed elsewhere, trademarks are not "property" like patents, copyrights, and trade secrets. Congress noted, however, one reason why it excluded trademarks from the definition of intellectual property is that the licensing of trademarks requires a quality control provision whereas the licensing of the other three types of intangible property does not have a similar requirement. See infra Part V.

174 The Hearing held by the Subcommittee on Monopolies and Commercial Law on H.R. 4657 did not include any discussion of trademarks. The only reference to trademarks appeared in a prepared statement by Thomas Hemnes, one of the four witnesses who testified at the hearing. The subsequent report accompanying the amended bill H.R. 5348 did not contain any explanation why trademarks were excluded from the intellectual property definition. See H.R. REP. No. 100-1012 (1988).

The Senate had its own version of the intellectual property bankruptcy protection bill, S. 1626. The report accompanying the bill contained a brief reference to trademarks under the "Other Matters" subheading and in the "Section-by-Section Analysis." See S. REP. NO. 100-505, at 5, 7 (1988). 
exercise quality control. ${ }^{175}$ As discussed infra Part V, such a belief is contrary to the modern quality control practices for trademark and should not serve as the reason for excluding trademarks from the Paradigm.

\section{Perpetuating the Paradigm}

Since the creation of the Paradigm, bankruptcy courts have applied the IPLBA without questioning its rationale for excluding trademarks from the definition of intellectual property. ${ }^{176}$ Some courts' uncritical application of the IPLBA is due to their unfamiliarity with intellectual property law in general, and trademark law in particular. ${ }^{17}$ For other courts, it is a matter of first impression whether a licensee retains the right to use a trademark under the IPLBA after the licensor's bankruptcy rejection. ${ }^{178}$

Lacking a comprehensive understanding of intellectual property, the bankruptcy court in In re HQ Global Holdings, Inc., allowed the debtor to reject trademark license agreements so that the debtor could use the marks in the localities where the franchisees once operated. ${ }^{179}$ Under the agreements, the franchisees received exclusive rights to use the trademarks and service marks in their business. ${ }^{180}$ The court noted that the IPLBA affords protection to licensees of intellectual property other than trademarks, and accordingly authorized the rejection. ${ }^{181}$ The court's decision effectively extinguished the franchisees' exclusive right to use

175 See infra Part V.

${ }_{176}$ See John P. Musone, Comment, Crystallizing the Intellectual Property Licenses in Bankruptcy Act: A Proposed Solution to Achieve Congress' Intent, 13 BANKR. DEV. J. 509, 516-27 (1997) (analyzing post-IPLBA case law concerning intellectual property licenses and identifying how judicial inquiry under traditional bankruptcy mechanism failed to realize congressional intent of removing threat to development of American technology).

17 See In re New York City Shoes, Inc., 84 B.R. 947, 949 (Bankr. E.D. Pa. 1988) (noting that trademark law was uncharted waters for court); see also William, supra note 118, at 39798 (noting courts have difficulty reconciling principles of bankruptcy law with those of intellectual property law due to "basic misunderstanding by the courts of the unique qualities of intellectual property").

${ }_{178}$ See In re Centura Software Corp., 281 B.R. 660, 662 (Bankr. N.D. Cal. 2002) (acknowledging as a matter of first impression the question whether "following a debtor's rejection of a license agreement that grants a counter-party a license to use the debtor's software and trademarks ... the counter-party [may] continue to use the trademarks after electing to retain its right in the software").

179290 B.R. 507 (Bankr. D. Del. 2003).

$180 \quad$ Id. at 509.

181 Id. at 512-13. 
the trademarks. ${ }^{182}$

In another case, In re Centura Software Corp., the bankruptcy court also authorized the debtor licensor's rejection of a trademark license agreement. ${ }^{183}$ The decision in Centura Software seems quite harsh in light of the fact that the licensee received the right to use both software and trademarks under the license agreement. ${ }^{184}$ Under the IPLBA, the licensee could elect its protected right to retain the software, but not the trademark. ${ }^{185}$ The licensee elected its protected right under the IPLBA, retaining the right to market and sell the software under the license agreement. ${ }^{186}$ Such a right, however, does little good if the licensee does not have the right to use the trademark in the marketing and sale of the software. ${ }^{187}$ The bankruptcy court extinguished the licensee's trademark license because IPLBA does not explicitly provide protection for trademark licenses, ${ }^{188}$ and because the licensee raised the issue too late. The licensee had already retained its software license to market and use after the debtor licensor made the rejection. ${ }^{189}$

These two reported cases confirm that the Intellectual Property Paradigm created by Congress affords trademark licensees less protection than patent, copyright, or trade secret licensees. Indeed, in cases where debtor licensors rejected technology licenses, bankruptcy courts applied the IPLBA and routinely permitted the licensees to continue to use the technology rights as long as the licensees pay the

182 Id. at 513

183281 B.R. 660 (Bankr. N.D. Cal. 2002).

184 Id. at 662-63 (noting that debtor licensor granted licensee exclusive right to market and sell Raima Software under Raima trademarks).

${ }^{185}$ Id. at 669 ("[A]lthough [the licensee] has elected to retain its $§ 365(n)$-protected rights to market and sell Raima Software ... , as far as Raima Trademarks are concerned, it will be left with but a $\S 365(\mathrm{~g})$ claim for damages resulting from being unable to use the trademarks in its business.").

186 Id.

${ }^{187}$ The licensee brought a motion under section $365(n)$ to retain its right to use the Raima Trademark. Id.

188 Id. at 673 ("Because section $365(\mathrm{n})$ is controlling post-rejection and it does not protect trademarks, the court holds that [licensee] cannot retain any trademark rights under the rejected [trademark agreement]. It cannot continue to use Raima Trademarks in its sale of Raima Software.").

${ }^{189} I d$. at 671-72 (" [I]n order to protect their entire bundle of rights, licensees like Raima UK 'must assert their rights early in the case, before the franchisor [licensor] receives court approval of its rejection decision.' The licensees must at that time persuade the bankruptcy court to weigh the equities and not to reject the agreement because its trademarks are integrally linked to other intellectual property.") [brackets in original]. The court, therefore, refused to weigh equities. Id. 
royalty fees. ${ }^{190}$ While technology licensees enjoy unfettered protection under the IPLBA, trademark licensees have much to fear when the debtor licensor is in bankruptcy. Trademark licensees are vulnerable, ${ }^{191}$ as they face the threat of unilateral rejection of the trademark license by the debtor licensor. ${ }^{192}$ A licensee or franchisee that has spent enormous resources to market its business and that now faces the threat of rejection from a bankrupt franchisor would be reluctant to protest because the IPLBA explicitly excludes trademark licensees from the special protection. ${ }^{193}$ The franchisor or licensor could use the threat of rejection to force the licensee into a new license agreement containing terms more favorable to the franchisor or licensor. ${ }^{194}$ Even if the licensee raises objections, courts, constrained by the plain meaning of the Act, often authorize rejection, regardless of the harsh consequences. ${ }^{195}$

\section{RETHINKING TRADEMARK PROPERTY}

The arrival of the Internet and the rise of global e-commerce have had a profound influence on trademarks, challenging trademark's current

190 See Schlumberger Res. Mgmt. Servs., Inc. v. Cellnet Data Sys., Inc., 327 F.3d 242, 250 (3d Cir. 2003) (applying IPLBA to protect licensees of technology agreements); Encino Bus. Mgmt., Inc. v. Prize Frize, Inc., 32 F.3d 426 (9th Cir. 1994) (holding licensee of technology agreements that retained right to use technology must pay royalty fees after debtor elected to reject agreements); In re El International, 123 B.R. 64 (Bankr. D. Idaho 1991) (holding that licensee of computer software system has right to retain use of technology in postrejection).

191 Some bankruptcy courts found that it is unnecessary to focus on the IPLBA in trademark license agreements because the IPLBA does not include trademarks. The courts applied instead the general provision, section 365(a), wherein the trustee or debtor has the right to reject an executory contract, the trademark license agreement, as long as the rejection is of sound business judgment. See generally In re Blackstone Potato Chip Co., 109 B.R. 557 (Bankr. D. R.I. 1990).

${ }_{192}$ The threat is very real as seen in In re HQ Global Holdings, Inc., 290 B.R. 507 (Bankr. D. Del. 2003), where the franchisee had no statutory right to retain the right to use the trademarks in the territories upon rejection by the franchisor.

${ }_{193}$ In both HQ Global Holdings and Centura Software the franchisee and licensee resorted to litigation to assert their rights to use the trademarks, but they were unsuccessful. Id. at 507; In re Centura Software, 281 B.R. at 660.

194 See Stuart M. Riback, Intellectual Property Licenses: The Impact of Bankruptcy, 722 PLI/Pat 203, 209 (2003) (observing advantageous position of debtor licensor over trademark licensees).

${ }_{195}$ See In re Centura Software, 281 B.R. at 670 ("If a statute can be interpreted on its face, it is not necessary to delve into its legislative history. This is because, where the language is clear, judicial inquiry is complete. Here, the clarity of $\$ 365(n)$ makes it unnecessary and inappropriate to look into its legislative history. Because Congress has unambiguously indicated that trademark licenses are to be excluded from $\S 365(n)$, it does not allow the court to weigh the equities of this case."). 
black sheep status in the Intellectual Property Bankruptcy Paradigm.

\section{A. The Trademark as the Global Domain Name}

Many trademarks today are no longer confined to a particular geographical location. ${ }^{196}$ Rather, they have become world marks within the global, electronic medium of commerce. ${ }^{197}$ A trademark registered as a domain name on the Internet is unique in its immediate global presence. ${ }^{198}$ Indeed, the trademark as a domain name is accessible by any person who has Internet access. ${ }^{199}$ Further, the trademark as domain name is unique because there is only one domain name in a particular Top-Level-Domain. ${ }^{200}$ This universality of trademarks as domain names

196 See David J. Franklyn, Owning Words in Cyberspace: The Accidental Trademark Regime, 2001 WIS. L. REV. 1251, 1280-81 (2001) (noting that Internet global medium has changed territorial feature of trademarks to become global trademarks).

${ }_{197}$ See id. at 1281 (stating that trademarks as domain names are now "one-world" trademarks due to worldwide computer network and exclusivity uniqueness of domain names).

198 See Laurence R. Helfer \& Graeme B. Dinwoodie, Designing Non-National Systems: The Case of the Uniform Domain Name Dispute Resolution Policy, 43 WM. \& MARY L. REV. 141, 155 (2001) (noting uniqueness of each string of alphanumeric character as domain name and its global Internet presence). The global nature of trademarks adds an international dimension to trademark infringement cases, particularly with respect to the assertion of personal jurisdiction over foreign defendants who have no contact with any forum in the United States. See Serge G. Avakian, Comment, Global Unfair Competition in the Online Commerce Era, 46 UCLA L. REV. 905, 931 (1999) (discussing global reach of trademark use over Internet and how such reach has impact on whether courts have personal jurisdiction over foreign defendants).

199 See Mo Zhang, Governance of Internet Domain Names Against Cybersquatters in China: A Framework and Legal Perspective, 26 HASTINGS INT'L \& COMP. L. REV. 51, 52 (2002) (stating that because domain name "possesses two distinctive features - the global presence because it is accessible from anywhere in the world and the extraterritorial exclusivity because it is not available to any subsequent registrants universally - its function as a 'universal resource locator' or 'business identifier' has become significant"). Unfortunately, the unique features of domain names in the global Internet medium have become a driving force for cybersquatting of trademarks on the Internet. U.S. law has responded to the worldwide cybersquatting of U.S. trademarks by enacting the Anticybersquatting Consumer Protection Act. See Dawn C. Nunziato, Freedom of Expression, Democratic Norms, and Internet Governance, 52 EMORY L. REV. 187, 258 (2003) (noting that under in rem provision of ACPA, trademark owners can enjoin cybersquatting by initiating action against domain name, not foreign registrant); Brent T. Yonehara, Landoftherisingsun.co.jp: $A$ Review of Japan's Protection of Domain Names Against Cybersquatting, 43 IDEA 207 (2003) (comparing U.S. law and Japanese law in curbing cybersquatting of protected trademarks on Internet).

${ }^{200}$ Unrestricted Top-Level-Domains ("TLD") include aero, .biz, .com, .coop, .info, .museum, name, net, and .org. There are second-level domains within these TLDs. Potential registrants can obtain domain names in a particular TLD or a domain name for a second-level domain within the TLDs. A second-level domain and the domain name attached to it must also be unique: "the DNS would break down if the domain names for 
greatly enhances the value of the trademarks. ${ }^{201}$

For many Internet companies, having the right domain name is crucial for survival in the challenging e-commerce sector of the economy. ${ }^{202}$ Internet companies rely on their domain names to attract and retain visitors to their websites. ${ }^{203}$ Internet surfers use domain names to search for websites. ${ }^{204}$ In the last few years, several domain names have become familiar source signifiers. Yahoo.com, ${ }^{205}$ travelocity.com, ${ }^{206}$ and

different locations within the TLDs were identical. Therefore, once a second-level domain has been registered, no one can register an identical domain name within that top level domain. A second-level domain holder can then create lower-level domains within their second-level domain." Ryan R. Owens, Note, Domain Name Dispute Resolution After Sallen v. Corinthians Licenciamentos \& Barcelona.com, Inc. v. Excelentisimo Ayuntameiento de Barcelona, 18 BERKELEY TECH. L.J. 257, 261 (2003).

201 Trademark owners believe that if their trademarks are registered as domain names by cybersquatters, the value of the domains decrease each day as they are held by the cybersquatters who prevent potential customers reaching the trademark owners' websites. Luke A. Walker, ICANN'S Uniform Domain Name Dispute Resolution Policy, 15 BERKELEY TECH. L.J. 289, 307 (2000).

${ }^{202}$ See Angela L. Patterson, Comment, With Liberty and Domain Names for All: Restructuring Domain Name Dispute Resolution Policies, 40 SAN DIEGO L. REV. 375, 385-86 (2003) (noting that domain name has become standard part of company's contact information and that possession of domain name that is also trademark or brand "leads to increased sales, trades, and other transactions").

${ }^{203}$ Internet companies enforce their trademarked domain names by pursuing registrants who obtained domain name registrations that incorporate the trademarks in bad faith. For example, Yahoo brought a proceeding against the registrant of yahooth.com and was successful. See Yahoo!, Inc. v. Somsak Sooksripanich and Others, WIPO Case No. D2000-1461 (Jan. 29, 2001), available at http://arbiter.wipo.int/domains/decisions/html /2000/d2000-1461.html (last visited Mar. 4, 2004). The panel decided that the registrant "intentionally attempted to attract Yahoo's customers to the registrant's websites and prevented Yahoo from reflecting its trademark by using the domain names." Areeya Ratanayu, Cybersquatting in Thailand: The Thai Trademark Act and the Uniform Domain Name Dispute Resolution Policy, 1 BUFF. INTELL. PROP. L.J. 203, 212 (2002).

204 An Internet user has two common methods of searching for a particular website. She can type a domain name into a browser or use a search engine. Brookfield Comm. Inc. v. W. Coast Ent. Corp., 174 F.3d 1036, 1044 (9th Cir. 1999). The easier method is a search by domain name. See Interactive Prods. Corp. v. a2z Mobile Office Solutions, Inc., 326 F.3d 687, 691 (6th Cir. 2003) (observing that Internet users who are seeking to locate web resources often use domain names for searches); Panavision Int'l, L.P. v. Toeppen, 141 F.3d 1316, 1327 (9th Cir. 1998) (noting that specific website is most easily located by entering its domain name into browser).

${ }^{205}$ The Yahoo website is the most visited web site according to Alexa.com, an Amazon.com company. See http://www.alexa.com/site/ds/top_500 (last visited July 16, 2003). In 2000, Yahoo was the second most visited web site according to a Nielson/Netratings in August 2000. Neil Weinstock Netanel, Cyberspace 2.0, 79 TEX. L. REV. 447, 476 n.116 (2001) (book review).

206 Travelocity is ranked thirteenth by Web100.com. See http://www.web100.com /listings/all.html (last visited July 16, 2003). 
google.com ${ }^{207}$ are just a few examples. These domain names function as trademarks and are entitled to the protection of trademark law. ${ }^{208}$

The recent collapse of the e-commerce bubble has forced many Internet-based companies into insolvency. ${ }^{209}$ Imagine that a licensor, who owns a number of trademarked domain names and who licenses those domain names to third parties, is now in bankruptcy. ${ }^{210}$ The bankrupt licensor decides to reject the licenses relating to domain names. The rejection will severely disrupt the licensees' business, perhaps much more than in the non-Internet context. The effects are more pronounced in the field of Internet commerce because the domain name has become the storefront of the licensee's business; ${ }^{211}$ global Internet customers reach the licensee's website through the domain name. ${ }^{212}$ Without the

207 Google is ranked first among the top search engines on the Internet. See http:/ / search-engines.nettop20.com (last visited July 16, 2003).

208 Indeed, these domain names are registered as trademarks. Travelocity has been registered for a number of classes of services. For example, Travelocity with the registration number 2,254,700 is for electronic retailing, travel, and hotel reservation services. Yahoo, with registration number $2,159,115$, is for electronic mail services and with 2,403,227 for online retail and mail order services, telecommunication, and multiple-user access to computer networks. Google's trademark application has a serial number 75,978,469. See http:/ / tess2.uspto.gov/bin/gate.exe (last visited Mar. 4, 2004).

209 Andrew M. Kaufman, Counseling the Financially Distressed Technology Company: Finding and Preserving Value in E-commerce Assets, 697 PLI/Pat 69, 75 (2002) (stating that number of Internet companies that have failed in last few years is "staggering"); Agin, supra note 88, at 379 (noting that .com start-ups are now "failing in record numbers as the business cycle turns downward"); see also Myers, supra note 2, at 4 (stating that numerous e-companies have either closed or declared bankruptcy, leaving behind creditors and investors and "the bankruptcy courts and lawyers, who must now decide how traditional laws apply to these new misfits of the business world").

${ }_{210}$ See Kaufman, supra note 209, at 90, 95 (noting that domain names are important assets of e-commerce companies, and suggesting that creditors should perfect their security interest in domain names prior to e-commerce companies becoming insolvent).

${ }^{211}$ See Philip G. Hampton, Legal Issues in Cyberspace, 713 PLI/Pat 629, 637 (2002) ("Commercially, a domain name is an online storefront."); Myers, supra note 2, at 48 (stating that, since Internet is thought of as virtual marketplace, domain is thought of as "virtual storefront or identifier of e-commerce company"); Heather E. Nolan, Protecting Consumers from Cybersquatters: Is the ACPA Standing Up?, 14 LOY. CONSUMER L. REV. 175, 177 (2002) (stating that domain names are awnings of electronic storefronts); Christina M. Lemon, Comment, Internet Domain Names, Cybersquatting and the Right of Publicity: Where Does the Right Belong in Cyberspace?, 24 WHITTIER L. REV. 291, 293 (2002) (noting that domain names have become online storefronts).

${ }_{212}$ See Panavision Int'l, L.P. v. Toeppen, 141 F.3d 1316, 1327 (9th Cir. 1998) (finding that domain names have functional use beyond being mere addresses, as they help customers reach intended websites, avoiding cumbersome use of Internet search engines); Hampton, supra note 211, at 637 (stating that domain name is "unique and permanent, i.e., a web fingerprint. It can create, reinforce and extend a brand and provide a single point of contact for customers, investors, partners and suppliers."). 
domain name, the licensee's website is not operational, ${ }^{213}$ and is unconnected to the global electronic world of commerce. ${ }^{214}$ To reject the license relating to the domain name is to extinguish the licensee's entire global e-commerce business. ${ }^{215}$

Further, the licensee may have devoted substantial resources to build the website, both the software structure and the contents, and to maintain the website for Internet business. ${ }^{216}$ The licensee likely has spent advertising resources on the domain name to attract customers to its website. ${ }^{217}$ The rejection of the license relating to the domain name

${ }^{213}$ Since domain names are memorable alphanumeric characters that are correlated to websites' IP addresses, Internet users can access a particular website by entering domain names, instead of the website's cumbersome IP address. Without the domain names, the websites are not connected to the network. See Robert V. Donahoe, Beyond.com: What Risk Does the Explosive Growth of Top Level Domains Pose to Your Trademark: Can You Get Any Relief?, 4 TUL. J. TECH. \& INTELl. PROP. 59, 61 (2002) (noting that each IP address is numerical identification used to locate specific computer connected to World Wide Web); see also Am. Online, Inc. v. Huang, 106 F. Supp. 2d 848, 851 n.5 (E.D. Va. 2000) (noting that web page is identified by its Uniform Resource Locator ("URL"), which includes domain name, identifies file, and indicates protocol required to access file); Justin Hughes, The Internet and The Persistence of Law, 44 B.C. L. REV. 359, 377 (2003) (noting each domain name is memorable alphanumeric name that is overlaid upon and corresponds to actual Internet address).

${ }^{214}$ "A significant purpose of a domain name is to identify the entity that owns the web site." Panavision, 141 F.3d at 1327; see also Gillian K. Hadfield, Privatizing Commercial Law: Lessons from ICANN, 6 J. SMALL \& EMERGING BUS. L. 257, 280 (2002) (asserting that "unique and reliable link between particular provider of a website and a domain name" promotes "efficiency by reducing the costs of search and structure a reputation mechanism to provide incentives for sellers to provide goods and services of a consistent level of quality").

${ }^{215}$ Indeed, the licensee will no longer have its storefront in the global e-commerce world. Customers will not be able to reach the licensee's website without the domain name. See Panavision, 141 F.3d at 1327 (noting that domain names help customers to reach intended websites); see also G. Gervaise Davis III, Internet Domain Names and Trademarks: Recent Developments in Domestic and International Disputes, 21 HASTINGS COMM \& ENT. L.J. 601, 607 (1999) (noting decline in traffic when there is change in Internet address that causes consumers to be unable to locate desired website).

${ }^{216}$ Many web sites today are sophisticated portals where business transactions are made and relationships with customers, partners, investors, consultants, and employees are built in real time. See Thomas M. Laudise \& Leonard T. Nuara, How to Contract for a Successful E-commerce Development Project: Beating the Odds, 58 Bus. LAW. 299, 300-01 (2002) (observing sophistication of websites in e-commerce and that cost for developing ecommerce site is in millions of dollars).

217 See Bruce Abramson, From Investor Fantasy to Regulatory Nightmare: Bad Network Economics and the Internet's Inevitable Monopolists, 16 HARV. J.L. \& TECH. 159, 178 (2002) (analogizing costs of advertising spent by Internet companies to equipment cost spent by traditional company). Branding is often the largest cost for an Internet company. Id; see also Greg Johnson, The Costly Game for Net Names, L.A. TIMES, Apr. 10, 2000, at A1 (reporting strategy employed by some Internet companies to offset their advertising costs by spending significant sum to purchase memorable domain names). 
will cause the licensee to suffer significant interruption, disruption, and loss of business. ${ }^{218}$ Given that the licensee is operating in the unstable ecommerce world, ${ }^{219}$ if the licensee faces the rejection, it may also be threatened with insolvency.

Since e-commerce is still in its nascent stage, the rejection of the license relating to trademarked domain names will cripple the growth and stability of e-commerce. Moreover, bankruptcy estates and creditors will not benefit from the rejection of trademarked domain names because the domain name loses its value when it is no longer associated with a particular website. ${ }^{220}$ Essentially, the value of the trademarked domain name is in danger as the rejection threatens to jeopardize the very goodwill it purports to preserve for the benefits of the estate, unsecured creditors, and the consumer.

\section{B. Trademark Licenses Integrated With Other Intellectual Property}

Companies may own numerous types of intellectual property assets and often license patents, copyrights, trade secrets, and trademarks to the same licensees. ${ }^{221}$ For example, a franchisor may license the right to

${ }^{218}$ See Freeman, supra note 88 , at $872-73$ ("The value of a web site and the traffic generated by it stems from the goodwill and reputation of the domain name."). Moreover, the loss of a domain name will disconnect the website from the global computer network and e-commerce. See Stefan Bechtold, Governance in Namespaces, 36 LOY. L.A. REV. 1239, 1242 (2003) (noting that Voteauction.com lost its domain name because registrar and registry excluded domain names from authoritative list recognized by all computers connected to Internet). If the e-company obtains a new domain name, that alone will cause a significant decrease in the traffic to the website. Freeman, supra note 88 , at 872 .

${ }_{219}$ See Abramson, supra note 217, at 177-78 (analyzing explosive growth and fast descent of e-commerce, and asserting that failure of e-commerce bubble is due to incomplete understanding of network economics); Robert W. Hahn \& Anne Layne-Farrar, Is More Government Regulation Needed to Promote E-commerce?, 35 CONN. L. REv. 195, 206 n.71 (2002) (suggesting that failures of e-commerce businesses may be caused by lack of privacy protection for consumers on Internet); Tapio Puurunen, The Judicial Jurisdiction of States Over International Business to Consumer Electronic Commerce from the Perspective of Legal Certainty, 8 U.C. DAVIS J. INT'L. L. \& POL'Y 133, 138 (2002) (asserting that uncertainty about jurisdiction norms hinders development of e-commerce).

${ }^{220}$ Since each domain name is unique, the licensee loses the exclusive right to use the domain name. Such loss will cause the domain name to decrease in value because the domain name has built its goodwill at the website through the traffic to the website. See Freeman, supra note 88 , at 872 (stating that domain name loses its value through transfer or abandonment).

221 See generally Craig J. Madson, Patent Misuse in Franchise Agreements: A Ripple on the Waters of Franchise Law, 20 FRANCHISE L.J. 107, 107 (2001) ("Many of today's franchise agreements will include not only the typical rights to use the franchisor's name, trademark, and know-how, but also the rights to use or otherwise take advantage of the franchisor's patents."); Squyres, supra note 167, at 490 (noting that trademark owners license 
use certain secret processes and formulas for the manufacture of rum products along with the right to use the name Matu for the distribution and sale of the rum products. ${ }^{222}$ If the franchisor is in bankruptcy and subsequently rejects the license agreement, the rejection would not automatically result in the termination of the franchisee's right to the secret process and formulas, nor would it eliminate the licensee's right to manufacture and sell the rum products. Under the IPLBA, the franchisee has the option to retain these rights. ${ }^{223}$ Yet ironically, under the IPLBA, the franchisee could not retain the right to use the name Matu for the sale of the rum products. ${ }^{224}$ In addition, the franchisor could not sell rum products manufactured according to the secret processes and formula, but it could use the trademark Matu to distribute and sell other products. ${ }^{225}$ Such a result would harm the franchisee by preventing it from using the Matu trademark to market what is, in effect, Matu rum products. ${ }^{226}$

A trademark licensee, in a similar situation as the franchisee in the above example, often is the entity that built the goodwill in the trademark through the actual use of the trademark in connection with the secret processes and formula or other intellectual property protected under the IPLBA. ${ }^{227}$ The value of the secret processes and formula is

trademarks as "part of an entire package which involves the licensing of know-how or special technological processes or techniques").

22 The example is based on In re Matusalem \& Matusa of Fla., Inc., 158 B.R. 514 (Bankr. S.D. Fla. 1993).

${ }^{223}$ See id. at 521-22 ("Even if rejection were permitted, it would not automatically result in the termination of [franchisee's] exclusive rights within its territorial area to the secret process and formulas used to make rum products or [franchisee's] exclusive rights to manufacture and sell these products within its territorial area.").

${ }^{224} I d$. at 522 (noting that upon rejection, debtor franchisor could use trademark outside exclusive territory of franchisee, "which it can do now, but could not sell rum under the rum label made with secret formula in" franchisee's exclusive territories).

${ }^{225}$ Id. (stating that debtor "could use the name outside the exclusive territory of [franchisee] ... but could not sell rum under the rum label made with the secret formula in [franchisee's] exclusive territories").

${ }^{206}$ Id. (concluding proposed rejection "would utterly destroy the business of" franchisee).

27 One commentator has urged that in circumstances where franchisees were granted exclusive use of a trademark in an exclusive territory of franchise operation, the franchisees should upon termination of the franchise agreement have the right to use the goodwill they have built. See Robert W. Emerson, Franchising Covenants Against Competition, 80 IoWA L. REV. 1049, 1092 (1995) ("When franchisees have contributed significantly to the goodwill value of a franchised trademark, enforcement of noncompetition covenants that prevent those franchisees from using the goodwill they helped to establish seems particularly harsh. ... Franchisees should be permitted the same right to use their own goodwill and skills to compete against a former franchisor."). 
further developed and enhanced by the association with the trademark. ${ }^{228}$ Since the rum products are sold under the same trademark each time, the value of the trademark is dependent on the trademark actually being used with the secret processes and formulas. ${ }^{229}$ The value of the trademark will be destroyed because while the franchisor could use the trademark, it could not use it in connection with the manufacture, distribution, and sale of the rum products that were previously sold under the Matu trademark. ${ }^{230}$ The result would diminish the value of the trademark and its associated goodwill, thereby benefiting neither the estate nor its unsecured creditors.

Further, such mix-matched use of the trademark may cause consumer confusion and destroy the established goodwill in the trademark itself. ${ }^{231}$ To return to the Matu rum hypothetical, the consumer has already come to associate the Matu label with the goodwill that has been established through the use of the trademark with the secret processes and formula. The consumer would soon discover that the Matu label no longer guarantees the same quality once the debtor franchisor starts to sell a different type of rum, because the franchisee has elected to retain the exclusive right to use the know-how of the rum products as permitted under the IPLBA.

This example illustrates how the license of a trademark can be closely interrelated with the license of the other intellectual property rights that are explicitly protected under the IPLBA. The severance of the

${ }^{228}$ Similarly, there are synergies between patents and trademarks that provide complimentary effects for the overall protection of the intellectual property assets in the marketplace. Parchomovsky \& Siegelman, supra note 10, at 1473.

229 The value of the trademark lies in the goodwill associated with products or services. See 1 Jerome Gilson et al., Trademark Protection and Practice § 1.03 [7] [a] (2002) (stating that trademark is considered property of sort, intellectual property, which derives its value from goodwill associated with product). Moreover, as courts have recognized that a purpose of trademark law is to protect the consumers from being misled, the purpose "may be undercut by materially different products that have the same trademark because such products may confuse consumers and erode consumer goodwill toward the mark." Laurence P. Colton \& Nigam Acharya, Intellectual Property, 53 MERCER L. REV. 1473, 1489 (2002).

230 Matusalem \& Matusa, 158 B.R. at 522 (concluding that in addition to destroying franchisee's business, proposed rejection was not beneficial to debtor as its new proposed business venture lacked realistic expectation of success).

${ }^{231}$ The trademark is now effectively transferred back to the licensor, who then uses the trademark divorced from its established goodwill in selling rums that are different from those with which the consumer has come to associate the trademark. Such trademark practice is akin to assignment in gross. See Note, Badwill, 116 HARV. L. REV. 1845, 1851 (2003) (discussing prohibition of sale or assignment of trademarks "in gross" - that is, separate from their associated goodwill). 
interrelationship under the Paradigm does not accord with modern business practice, which often relies on the simultaneous use and licensing of multiple forms of intellectual property. ${ }^{232}$ Consequently, excluding trademarks from the Intellectual Property Bankruptcy Paradigm does not assist the debtor, unsecured creditors, or the franchisee.

\section{ENDING THE EXCLUSION OF TRADEMARKS}

In light of both the changing role of trademarks in the Internet economy ${ }^{233}$ and the integration of trademarks with other protected intellectual property in licensing arrangements, ${ }^{234}$ the IPLBA should be amended to include trademarks within its protections.

The current section 365(n) grants the debtor enhanced bargaining leverage, as the trustee or debtor-in-possession could threaten rejection in order to obtain favorable terms in renegotiation with the trademark licensees. ${ }^{235}$ Since the plain language of section 365 excludes trademarks, rejection is not just a threat, but a reality as bankruptcy courts interpret the statute literally, giving deference to the debtor's business judgment in the rejection. ${ }^{236}$ Thus, if the licensor files for bankruptcy, the licensee's business may be in peril if it depends heavily on the trademark license. Particularly if the licensee has spent substantial resources building the goodwill of the trademark, preserving the trademark, and executing an aggressive marketing campaign, the licensee may be forced either to renegotiate the license under terms much more favorable to the debtor,

${ }^{232}$ See generally Parchomovsky \& Siegelman, supra note 10, at 1460-61.

233 See supra Part IV.

234 Id.

${ }^{235}$ See Riback, supra note 194, at 209 ("It should be obvious that $\$ 365$ can give a debtorlicensor enormous bargaining leverage, particularly if the licensee's business depends on the license. The debtor can use the threat of rejection to renegotiate the terms of licenses.").

${ }^{236}$ See id. (noting that courts generally uphold debtor's decision to reject so long as it is good faith exercise of business judgment that may benefit estate). Courts rarely disallow rejection. Id. (discussing 1983 patent and trademark license case wherein court declined rejection because rejection would utterly destroy licensee and harm was "vastly disproportionate to any benefit that creditors might receive").

In evaluating whether the debtor's rejection is an exercise of business judgment, the court may consider additional factors, including whether: 1) the contract burdens the estate financially; 2) rejection would result in a large claim against the estate; 3 ) the debtor showed real economic benefit resulting from the rejection; and 4) upon balancing the equities, rejection would do more harm to the nondebtor party than to the debtor if not rejected. In re G Survivor Corp., 171 B.R. 755, 757-58 (Bankr. S.D.N.Y. 1994). Generally, however, "absent a showing of bad faith, or an abuse of business discretion, the debtor's business judgment will not be altered." Id. at 757 . 
or face the consequences of rejection. ${ }^{237}$

The congressional failure to address the trademark license agreement rejection issues in the IPLBA was a result of Congress' reluctance to extend the IPLBA's protection to trademarks. ${ }^{238}$ The reluctance stems from concern over whether the debtor licensor can control the quality of the licensee's products or services if the licensee is allowed to continue to use the trademark upon the licensor's rejection of the trademark license agreement. $^{239}$ Whether the reluctance warrants the exclusion of trademarks from the protection provided under the IPLBA must be examined in light of the prevalent practices of trademark licensors in license arrangements. ${ }^{240}$

Though it is true that a trademark license often includes the licensor's quality control provision in order to avoid a "naked license," frequently the licensor itself does not conduct the quality control, but merely imposes a quality standard provision to which the licensee must adhere. ${ }^{242}$ The licensor itself does not attend to the provision by

${ }^{237}$ Smolinksy, supra note 91, at 253. See Sally Abel, Quality Control in Trademark Licensing, 736 PLI/Pat 383, 395 (2003) (stating that debtor licensor's rejection of trademark license will have deleterious effect since licensee has built thriving business in large part dependent on underlying trademark license).

${ }^{238}$ A commentator has noted that Congressional reluctance to extend the benefits of section 365(n) to trademark licensees produces a "serendipitous result [that] hardly seems just." Abel, supra note 237, at 395.

${ }^{239}$ Congress essentially ducked the problem because trademark licensing relationships depend "to a large extent on control of the quality of the products or services sold by the licensee." S. REP. NO. 100-505, at 5 (1988).

${ }^{240}$ Criticism of the Congressional concern "in the name of quality control considerations" in allowing a debtor to reject a trademark license seems "an arbitrary, counterproductive result in the context of trademark licensing today." Abel, supra note 237, at 395.

${ }^{241}$ See Progroff, supra note 36, at 21 (stating that trademark license is "naked" if it does not contain quality control provisions); see, e.g., Barcamerica Int'l USA Trust v. Tyfield Imps., Inc., 289 F.3d 589, 595 (9th Cir. 2002) ("[N]aked licensing may result in the trademark ceasing to function as a symbol of quality and controlled source."); Stanfield $\mathbf{v}$. Osborne Indus., Inc., 52 F.3d 867, 871 (10th Cir. 1995) ("Naked (or uncontrolled) licensing of a mark occurs when a licensor allows a licensee to use the mark on any quality or type of goods the licensee chooses.").

${ }^{242}$ Trademark license agreements frequently include a Quality Control provision, such as the one provided in William J. Seiter, On Your Mark, Recent Ninth Circuit Opinions Indicate What Should and Should Not Be Included in a Trademark Licensing Agreement, 25 L.A. LAW 37, 44 (2003):

1. Quality Assurance. Licensee acknowledges that if the Licensed Products designed, manufactured, and sold by it were to be inferior in quality, design, material or workmanship as compared to Licensor's products associated with the Licensed Mark, the substantial goodwill that Licensor possesses in the Licensed Mark and its favorable public recognition would be impaired. Accordingly, 
frequently visiting the licensee's site to verify the quality of products or services. ${ }^{243}$ The standard of quality provision has become the norm because it is economically efficient for both licensors and licensees. ${ }^{244}$

Licensee represents and warrants that all Licensed Products shall be of a high standard of quality suited to exploitation of the Licensed Mark to its best advantage.

2. Sample Approvals. Before commencing production of any new Licensed Product or significant modification of an existing Licensed Product, Licensee shall furnish Licensor at Licensee's expense a reasonable number of samples thereof, including associated labels and packaging, and shall not manufacture, promote, advertise, distribute, or sell any such new or modified Licensed Product without Licensor's prior written approval. Upon request from time to time, Licensee shall furnish to Licensor without charge additional samples of any Licensed Product to facilitate Licensor's verification of the conformity of such Licensed Product to the approved form thereof.

See also Gregory J. Battersby \& Leonard T. Nuara, The License Agreement - A Mock Negotiation and an Analysis of Sample License Agreement, 608 PLI/Pat 299, 310 (2000) ("The Licensed Product shall be of a high quality which are at least equal to comparable products manufactured and marketed by COMPANY and in conformity with a standard sample approved by OWNER.").

${ }^{243}$ The licensor merely reserves the right to inspect the licensee's facility. The relevant reservation of Inspection Rights is as follows:

Inspection Rights. Throughout the term of this Agreement, Licensor and its designated representatives shall have the right, and Licensee shall ensure such right, at any time during ordinary business hours to inspect any factory, warehouse, showroom, business office, retail store, or other facility or premises used or occupied by Licensee, its employees, agents, affiliates, or subcontractors engaged in the manufacture, promotion, distribution, or sale of Licensed Products or associated labels or packaging, to inspect and test Licensed Products, and to take any other action necessary or useful, in Licensor's opinion in its sole discretion, to assure that the Licensed Products are produced and sold in compliance with this Agreement.

Seiter, supra note 242 , at 44 .

${ }^{244}$ In practice, many trademark license agreements do not include the Inspection Rights. See Battersby \& Nuara, supra note 242, at 335-36 (including typical trademark license agreement). The license agreement provides:

\section{NOTICES, QUALITY CONTROL, \& SAMPLES}

A. The License granted hereunder is conditioned upon LICENSEE'S full and complete compliance with the marking provisions of the trademark, patent and copyright laws of the United States.

B. The Licensed Products, as well as all promotional, packaging and advertising material relative thereto, shall include all appropriate legal notices as required by Licensor.

C. The Licensed Products shall be of a high quality which is at least equal to comparable products previously manufactured and marketed by LICENSOR under the trademarks. 
Further, the common practice today is to permit quality control of trademarks to take many forms, including an arrangement in which the licensor itself does not control the products' quality, but delegates this duty to the licensee, which has the expertise and incentive to maintain the agreed upon level of quality. ${ }^{245}$ Accordingly, this common practice with regard to quality control should alleviate the concern indicated in the legislative history. ${ }^{246}$ Moreover, a licensee that has invested substantial resources in building the goodwill of the trademark is not likely to destroy that goodwill by selling goods or products of materially different quality under the trademark. ${ }^{24}$

In addition, the quality control concern parallels the confidentiality of trade secret concern raised by those who opposed the legislative precursor to the IPLBA. ${ }^{248}$ There was a fear that permitting the licensee to retain its trade secret rights would destroy the confidentiality of trade secrets. Similarly, it was feared that the confidentiality provision would

D. If the quality of the Licensed Products falls below such quality, LICENSEE shall use its best efforts to restore such quality. In the event that LICENSEE has not taken appropriate steps to restore such quality within thirty (30) days after notification by LICENSOR, LICENSOR shall have the right to require that the LICENSEE cease using the Trademarks.

Another commentator has noted that the trademark licensor may exercise quality control by appointing the licensee as its quality control agent. See Weinberg, supra note 63, at 19 (noting that some courts have upheld practice of appointing licensee as licensor's quality control agent).

245 "Naked" licensing is avoided by having the licensor delegate to and rely on the licensee to maintain quality control. Abel, supra note 237, at 400 . Further, the trend of lessening the licensor's grip on quality control, as noted by a commentator, perhaps indicates that the licensor does not want to increase its potential liability and stifle the licensee. See Weinberg, supra note 63, at 408 (noting that too much quality control would lead to negative results such as licensee being stifled and licensor's potential liability being increased); see also Kera \& Davis, supra note 159, at 410 (reviewing trademark law and noting that modern case law is relatively generous toward trademark license arrangement, and that in 2003 only one trademark case addressed impermissible "naked" license wherein license failed to contain "quality control" recitation).

${ }^{246}$ See Abel, supra note 237, at 400 (stating that "Congress's hesitation to include trademark licenses within the definition of those 'intellectual property' licenses protected from a bankrupt licensor's rejection, cannot be sustained on the grounds that the quality control obligation distinguishes these executory contracts from other 'intellectual property' licenses.").

${ }^{247}$ In fact, the licensee who invests substantially to build its business using the licensed trademark wants to "obtain rights to protect the intellectual property in the trademark, instead of relying on the licensor to do so." Keyes \& Nyes, supra note 34, at 25 (stating that when licensee is building brand, it should attempt to secure exclusive right to use trademark in particular field of use and obtain right to protect trademark).

243 See Hearings, supra note 119. 
not be enforceable post-rejection. ${ }^{249}$ However, as witnesses at the hearing noted, such a concern had already been addressed in practice, as licensees that obtain trade secrets have an interest in protecting confidentiality. ${ }^{250}$ Moreover, either the debtor licensor or the licensee could seek a court order for confidentiality protection under bankruptcy law. ${ }^{251}$

Accordingly, the quality control issue can be addressed in line with what Congress has accomplished with respect to the confidentiality provision for trade secrets. ${ }^{252}$ Congress should explicitly amend the IPLBA to impose on trademark licensees the obligation to continue, for the remainder of the term of the license agreement, the quality control standard to which the licensees have agreed. ${ }^{253}$ This imposition should occur only if the licensee of a trademark license agreement desires to exercise the right to use the trademark license for the duration of the term. ${ }^{254}$ The new amendment will protect the consumer by maintaining the quality control standard for the goods under the licensed trademarks even if the licensor rejects the trademark license agreement. Consequently, the goodwill of the trademark will not be destroyed as the licensee continues to adhere to the existing quality control obligation.

\section{CONCLUSION}

The Intellectual Property Bankruptcy Paradigm excludes trademarks from the definition of "intellectual property" and the special bankruptcy protection afforded only to patents, copyrights, and trade secrets. The Intellectual Property Bankruptcy Paradigm has no foundation as trademarks have extensively evolved into global trademarked domain names, the licensing of trademarks along with the quality control requirement has become increasingly liberalized, and integrated licensing of different forms of intellectual property is more common. The exclusion of trademarks from the Paradigm perversely endangers

249 Id.

250 Id.

251 Id.

252 In fact, the confidentiality provision of trade secrets has already been addressed in section 107(b)(2) of the bankruptcy code. See id.

${ }^{253}$ See generally Battersby \& Nuara, supra note 244, at 335-36 (providing sample of trademark license agreement); Seiter, supra note 242, at 44 (same); Weinberg, supra note 63, at 408-09 (discussing trademark license agreement and quality control methods).

254 Unlike the confidentiality provision of trade secrets that has already been addressed in the bankruptcy code, adding a provision on the licensee's continued obligation to quality standard will not cause any redundancy. See Hearings, supra note 119. 
the very goodwill that the Paradigm purportedly protects. The exclusion of trademarks serves neither the interest of the bankrupt estate, the unsecured creditors, nor the consumer. Thus, it is time to shift the Paradigm with an amendment to the Intellectual Property Licenses in Bankruptcy Act. 